$10-2003$

\title{
Stock Market Liberalization and the Information Environment
}

\author{
Kee-Hong Bae \\ Korea University \\ Warren Bailey \\ Cornell University \\ Connie X. Mao \\ Temple University
}

Follow this and additional works at: https://fordham.bepress.com/crif_seminar_series

Part of the Finance and Financial Management Commons

\section{Recommended Citation}

Bae, Kee-Hong; Bailey, Warren; and Mao, Connie X., "Stock Market Liberalization and the Information Environment" (2003). CRIF Seminar series. 27.

https://fordham.bepress.com/crif_seminar_series/27 


\title{
Stock Market Liberalization and the Information Environment
}

\section{Kee-Hong Bae, Warren Bailey, and Connie X. Mao *}

\author{
Korea University, Cornell University, and Temple University
}

Partial draft: 23 October 2003

Do not distribute without permission

\begin{abstract}
We study the associations between openness to foreign equity investors and the information environment facing emerging market firms. Changes in openness are reflected in legal, regulatory, and cross-listing events, the fraction of stock available to foreign investors, and the size of U.S. portfolio capital flows. The information environment is reflected in firm-specific return volatility and in indicators of information production, uncertainty, and disagreement related to earnings announcements. We find that information measures typically increase with openness to foreign equity investment, particularly in the form of security cross-listings and aggregate portfolio flows.
\end{abstract}

JEL Classifications:

Keywords:

* Corresponding author: Warren Bailey, Johnson Graduate School of Management, Cornell University, Sage Hall, Ithaca, NY 14853-6201, 607-255-4627, fax 607-255-4627, wbb1@ cornell.edu. We are grateful to Thomson Financial for access to their I/B/E/S data.

(C) 2003 Kee-Hong Bae, Warren Bailey, and Connie X. Mao. 


\section{Introduction}

A key theme in restructuring economies in the developing world is opening stock markets to foreign portfolio investment. This can be accomplished by permitting foreign investors to enter the local stock market directly or by allowing local assets to trade in overseas stock markets. In theory, this permits developing economy firms to draw from the global pool of capital to undertake useful investments that generate profits and employment. Furthermore, the scrutiny of foreign investors, foreign equity analysts, and foreign stock listing standards can help resolve agency problems, effectively transmitting higher quality reporting and governance standards to developing-country firms (Obstfeld 1998, Stulz 1999).

There is much theory and empirical evidence to support the notion that opening a stock market to foreign investors is beneficial. Classic international asset pricing models such as Errunza and Losq (1985) show how the removal of capital barriers can reduce the cost of capital in a developing economy to global levels. Alexander, Eun, and Janakiramanan (1987) show that this may occur merely by cross listing a local stock in a foreign market. In empirical studies of the impact of loosening restrictions against foreign portfolio investment, Henry (2000) and Bekaert and Harvey (2000) find that the cost of capital declines significantly after market liberalization. In empirical studies of the cross listing of foreign securities on U.S. exchanges, numerous authors (see, for example, Foerster and Karolyi 1999 and Miller 1999) report evidence consistent with a lower cost of capital. Tandon (1997) finds that the listing of a closed end country fund in the U.S. market appears to lower the cost of capital in the local market. More generally, the evidence in Kaminsky and Schmukler (2002) suggests that liberalization tends to spur the process of institutional reform, not the other way around.

At the same time, there is growing concern among politicians, policy makers, economists, and investors that complete openness to global capital flows can cause problems. The Asian economic crisis that began in 1997 was characterized by large outflows of short- term capital that certainly aggravated the crisis, and may even have been responsible for starting it. Malaysia's outspoken Prime Minister Mahathir has argued that, "All in all, the present system, if there is a system at all, is messy, unreliable and 
destructive." Krugman (1998) and Stiglitz (1999) suggest that some degree of impediment to crossborder portfolio capital flows can smooth boom-and-bust cycles driven by rapid inflows and outflows of portfolio capital. Kaminsky and Schmukler (2002) find empirical evidence that emerging economies experience heightened boom-and-bust stock market cycles after liberalization while Bekaert, Harvey, and Lundblad (2002) find that decreased volatility of real activity indicators after liberalizations does not extend to emerging economies in recent years.

The purpose of our paper is to examine another facet of the impact of stock market liberalization on emerging stock markets. While a well functioning stock market is intended to provide plentiful and inexpensive capital, it should also increase the flow and use of information. More information can contribute to the decision-making processes of investors and managers, facilitate corporate discipline, and add value. ${ }^{2}$ By listing overseas and thereby submitting to foreign standards of reporting, regulation, and law, a company can benefit by submitting to what Admati and Pfleiderer (2000) refer to as "voluntary disclosure". Other models (Cantale, 1998, Fuerst, 1998; Moel, 1999; Huddart, Hughes and Brunnermeier, 1999) suggest that overseas cross listing yields a capital gain as a reward for signaling higher quality. Foerster and Karolyi (1999), Miller (1999), and Baker, Nofsinger, and Weaver (2002) find evidence consistent with enhanced information and visibility as a result of listing in the U.S. market while Lang, Lins, and Miller (2003) find that analyst coverage and earnings forecast accuracy increase with listing in the U.S. Doidge (2003) reports evidence that cross-listing in the U.S. affords greater protection to minority shareholders, which is consistent with the notion that "openness" promotes economic efficiency at the expense of entrenched local interests (Durnev, Morck, and Yeung, 2001). More generally, an entire capital market may be thought of as submitting to the demands of foreign investors from higher-quality environments when it loosens restrictions on foreign equity investors.

\footnotetext{
${ }^{1}$ Excerpt from his speech entitled "Revitalization of Japanese and East Asian Economies" at the Fifth Symposium of the Institute for International Monetary Affairs, in Tokyo, 2 June 1998.

${ }^{2}$ Durnev, Morck, and Yeung (2003), for example, find that an enhanced information environment for a firm contributes to efficient capital allocation decisions.
} 
Our paper adds a new dimension to the "impact of stock market opening" literature. We begin with the assumption that increased openness to foreign equity investment leads to specific informationrelated benefits such as higher-quality corporate disclosure and increased resources for information production and analysis. This implies a number of predictions that we test by examining how the information environment changes as openness to foreign equity investment changes. Across a sample of emerging economies, we compute three measures of openness to cross border capital flows based on explicit official liberalizations and equity cross listings in the U.S. and U.K., the fraction of the local stock market that is available to foreigners, and the flow of U.S. equity investment in and out of the local stock market. Thus, our measures of openness go beyond using only official liberalizations or only stock or fund cross-listings, combining many types of openness "events" with time series measures of the potential and actual trading of emerging market equities by foreigners. We relate the openness measures to several proxies for aspects of the information environment faced by the firms in our sample emerging markets. We seek to detect a beneficial impact of openness and liberalization on the information environment in developing economies. If, on the other hand, we can find no evidence of beneficial change in the information environment, our concerns about the presumed benefits of openness to foreign portfolio investment increase.

Our results indicate a strong association between changes in openness and changes in the information environment. Securities cross-listings and the scale of portfolio flows, in particular, are strongly associated with several facets of the information environment. Furthermore, there is some marginal evidence that de-liberalization events have the opposite effect on the information environment. Finally, it appears that causality runs from changes in openness to changes in the information environment, rather than in the other direction. [Should we discuss more of our findings?]

The paper is organized as follows. Section 2 details our methodology while Section 3 describes our data. Section 4 presents empirical results while Section 5 is a summary, discussion, and outline for further research.

\section{Testable hypotheses}


We start with the general assumption that increased openness to foreign portfolio investment conveys substantial benefits to an emerging market economy by improving the quality of the information environment faced by local firms. The "enhanced information environment" effect compliments the other documented benefits of increased openness including lowering the cost of capital, imposing improved governance and protection of investors, and disciplining firms to make better investment decisions.

To begin, we assume that official liberalizations and other changes in the openness of an emerging stock market to foreign equity investment increase the quality of corporate disclosure. Put another way, the local economy benefits as local firms are compelled to release better-quality earnings numbers, annual reports, and other types of disclosure. Leuz, Nanda, and Wysocki (2003) show that the quality of reported earnings is higher in environments that impose higher legal, regulatory, and disclosure standards on local firms. Lang, Raedy, and Yetman (2003) find that non-U.S. firms newly cross-listed in the U.S. supply higher quality disclosures that result in larger market responses. Cross-listed firms may offer less smoothed, more immediate reporting of economic losses to stave off the threat of legal or regulatory penalties (Skinner 1994, Ball, Kothari, and Robin 2000). Increased market-wide openness may prompt local firms to supply better disclosure to attract and retain foreign investors, even among firms that are not cross listed.

Additionally, we assume that the resources devoted to analyzing local firms increase when an emerging stock market becomes more open to foreign portfolio investment. Increased foreign investor access and interest spurs more information production by analysts, brokerages, traders, and other local and foreign participants in an emerging stock market. This prompts local firms to produce more disclosures and adhere more strongly to international norms of corporate governance, spurring local interest and investment in the local stock market as well. Lang, Lins, and Miller (2003) report that nonU.S. firms cross-listed in the U.S. have greater analyst coverage than other firms from the same country. Even for the case of a country, Canada, with disclosure standards similar to those in the U.S., Leuz (2003) finds that Canadian firms that cross-list in the U.S. have greater analyst coverage than other firms. 
We translate these ideas into specific testable hypotheses as follows. First, higher quality disclosures imply that earnings management and manipulation is less prevalent, earnings are less smooth and, therefore, earnings announcements typically contain larger surprises:

H1: The absolute value of earnings forecast errors increase as an emerging economy becomes more open to foreign portfolio investment.

$\mathrm{H} 1$ is a consequence of the notion that increased openness spurs the release of more accurate and useful information. As a consequence, more informative disclosures heighten stock price reactions to corporate information releases (Holthausen and Verrecchia 1990, Kim and Verrecchia 1991):

H2: Stock return surprises around earnings announcements increase as an emerging economy becomes more open to foreign portfolio investment.

There is an alternative to $\mathrm{H} 1$ and $\mathrm{H} 2$. In response to increased openness of an emerging stock market to foreign equity investment, listed firms may supply more pre announcement disclosures to guide analysts forecasts. Thus, analysts produce more accurate earnings forecasts, and forecast errors decrease. In Kim and Verrecchia (1991), return responses to earnings releases decrease as the amount of pre announcement information increases, since earnings releases are less surprising.

Our second basic prediction, that more resources are devoted to producing and processing firmspecific information as openness increases, leads to:

H3: The number of analysts following local firms increases as an emerging economy becomes more open to foreign portfolio investment. 
$\mathrm{H} 3$ reflects the general notion that a virtuous cycle of improved disclosure and increased interest from foreign (and local) investors leads to greater investment in information production that, in turn, spurs further investor interest and higher quality disclosure and governance among local corporations.

Third, with more resources devoted to studying local companies, the firm-specific component of return volatility that proxies for firm-specific information increases:

H4: Firm specific return volatility increases as an emerging economy becomes more open to foreign portfolio investment.

Roll (1988) suggests that low r-squared coefficients from regressing individual stock returns on common economic factors represent private firm-specific information. Morck, Yeung, Yu, and Zarowin (2003) find that high firm-specific return volatility is associated with stronger correlation between stock returns and future earnings, confirming an association between firm-specific return volatility and firm-specific disclosure and analysis.

We formulate one additional prediction using the intuition supplied in models such as those of Kim and Verrecchia $(1991,1994,1997)$. These models balance the precision of disclosures against the disagreement or "difference of opinion" that results from more information production and processing:

H5: Earnings forecast dispersion increases as an emerging economy becomes more open to foreign portfolio investment.

More disagreement and difference of opinion results from the increased disclosure, private information production, and information processing that we assume follow increases in openness to foreign portfolio investment. The struggle among analysts, traders, and other investment professionals to achieve consensus about individual stock values is a mark of a healthy, mature capital market. 
It is plausible that we may uncover evidence that is different or more complex than the predictions just outlined. For example, Lang, Lins, and Miller (2003) report that forecast errors are typically lower for cross-listed firms, although their sample largely spans one year and mixes firms from both developed and emerging markets. Leuz (2003) finds that earnings forecast accuracy for Canadian firms does not increase after U.S. listing, even though the number of analysts increases. Bailey, Karolyi, and Salva (2002) find that changes in market responses to earning releases after U.S. cross-listing are most prominent for developed-country firms that adopt lower-level U.S. listings, which is counterintuitive as emerging-market firms that select higher-level U.S. listing should experience the greatest change in their information environment.

\section{Data}

We begin with the names of the component firms of the Standard and Poor's Emerging Markets Database (EMDB). They represent significant firms from a cross-section of over forty emerging economies. However, data restrictions, as discussed in subsequent sections, limit the number of countries we are able to use. For example, the lack of sufficient Datastream or I/B/E/S records for such countries as Bahrain, Egypt, Morocco, Nigeria, Oman, Saudi Arabia, and Zimbabwe leads us to exclude them from our sample. We use as many countries, firms, and time periods as possible, and, as detailed below, some tests check for robustness over different subsamples of the available data.

\subsection{Proxies for openness to cross border portfolio flows}

We compute three proxies for the openness of a particular developing country to foreign portfolio investment. They are liberalization and cross listing events, the fraction of local market capitalization that is legally available to foreign investors, and the size of portfolio flows between a particular developing country and the U.S.

Events. We collect for each sample country dates of explicit official liberalizations, cross listing of domestic company shares on U.S. and U.K. stock markets, and listing of closed-end country funds on U.S. and U.K. stock markets. As previously discussed, classic theories suggest that such events can ease 
access to the local stock market by foreign investors, and a variety of studies associate such events with decreases in the cost of capital.

Table 1 lists (and Appendix 1 details) our sample of official liberalization, cross listings, and closed end fund listing events and dates. "Official liberalization events" are announcements of changes in legislation and regulation that ease foreign access to a country's local stock market. We begin with the major official liberalizations outlined by Bekaert and Harvey (2000) for the period through 1995 . We update their set of events through 2002 and also collect events for several countries not included in the Bekaert and Harvey sample. Our primary source is the list of significant events on Campbell Harvey's web page, ${ }^{3}$ plus other articles and online sources in a few cases. We restrict this new set of events to major liberalizations involving the stock market or affecting the ability of foreigners to buy and sell local equities. We also include several "de-liberalization" events, that is, events that raised, rather than loosened, foreign investment restrictions. See, for example, the description of the July 1995 event for Chile in Appendix 1. While our sample only includes a handful of such events, they allow us to see if the effect of raising capital barriers is opposite in sign to the effect of lowering such barriers.

A second group of "openness" events consists of overseas listings of stocks or closed end country funds. As classic theories like Alexander et al. (1987) indicate, an asset traded in both the home country and overseas can serve as a channel that effectively opens the home country capital market to the world. We obtain initial trading dates for ADRs listed in the U.S. from Bank of New York ${ }^{4}$ and for GDRs and ordinary listings in London from the London Stock Exchange. ${ }^{5}$ We build the list of closed end country fund listing dates from Bekaert and Urias (1996), Patro (2002), Campbell Harvey's web page, and other sources. As described in Table 1, we select the earliest event of each type that can be covered by our data.

3 www.duke.edu/ charvey.

4 www.adrbny.com.

5 www.londonstockexchange.com/international/default.asp. 
In addition to explicit liberalization and cross listing events, we adopt the structural breakpoints in net U.S. equity portfolio flows estimated by Bekaert and Harvey (2000). The net portfolio flow series are monthly. As discussed subsequently, we employ the gross portfolio flow series as a time-series explanatory variable in some of our tests. However, the Bekaert and Harvey breakpoints serve as dates around which "before versus after" tests can be constructed, in a manner similar to what we do with explicit liberalization and listing events. This alternative set of "events" is important because the effective dates of changes in openness may differ substantially from the formal dates of explicit liberalization events. As Bekaert and Harvey (2000) and other authors have indicated, identifying effective liberalization dates is problematic, and our use of alternative event dates helps address this concern.

Table 1 displays our five sets of liberalization and openness events. In addition to "official", "cross listing or country fund listing", "breakpoint", and "de-liberalization" events as previously described, we include a set entitled "earliest feasible liberalization". This is a reduced set that is spanned by both our stock market and I/B/E/S data sets. Its construction is detailed in the table. It is evident throughout the sample of events that data limitations constrain the events that can be used. For example, we must exclude earlier official liberalization for Chile and earlier closed end fund listings for Brazil because we do not have data extending sufficiently far back in time.

Investibility. We compute for each sample country the proportion of the local stock market capitalization that is available to foreign investors. The Emerging Markets Database (EMDB) of Standard and Poor's (formerly from the International Finance Corporation of The World Bank) offers a variety of aggregated and individual firm data from over forty developing countries. By examining legal, regulatory, and company-specific restrictions on foreign ownership, the percentage of the firm's equity available to foreign investors (that is, the firm's "investibility") is determined, and recorded on the database. ${ }^{6}$ The change in the proportion of the equity of the EMDB firms in a particular market that is available to

\footnotetext{
${ }^{6}$ Rouwenhorst (1999), Edison and Warnock (2001), and Bae, Chan, and Ng (2002) discuss problems such as survivorship bias and lags in updating the foreign ownership restrictions in the EMDB database. Bae, Chan, and $\mathrm{Ng}$ (2002) find that corrections to the EMDB methodology do not alter their finding that investibility is associated with higher return volatility and higher correlation with global factors.
} 
foreign investors serves as our "investibility" openness measure. Time-variation in each country's proportion occurs as foreign ownership limits and other controls on foreign investment vary with changes in local laws and regulations. Thus, it is a very specific indicator of the impact of legal limitations on foreign ownership of local equities.

Portfolio flows. Our third type of openness measure is computed from the size of portfolio flows between a particular developing country and the U.S. U.S. investors represent a significant fraction of the portfolio capital flows to and from emerging markets. The monthly flow of portfolio capital between the U.S. and virtually every country in the world is made available online by the U.S. Treasury Department starting with 1988 data. $^{7}$ We divide the sum of inward and outward flows of U.S. stock market investors by the market's capitalization as a proxy for the amount of portfolio activity crossing a particular country's borders in a particular month. While the previously defined "event" and "investibility" measures suggest the potential openness of the local capital market, the flow of portfolio capital represents the actual capital movements across an emerging market's borders.

\subsection{Proxies for the information environment}

We create several measures of the information environment faced by the emerging market firms in our sample. These measures will be related to the "openness" measures previously described.

Firm-specific volatility. For the purpose of characterizing the information environment, a key recent paper is Morck, Yeung, and Yu (2000). They decompose the volatility of individual stock returns from many countries into market-wide and firm- specific components, arguing that higher firm-specific volatility can indicate the willingness of analysts, traders, and other investors to produce firm-specific information. They find that the proportion of firm-specific return volatility is larger in countries with better investor protection, disclosure, and overall market quality, implying greater incentives to produce information and trade on it. This confirms their interpretation of the firm-specific variance as a measure

\footnotetext{
${ }^{7}$ The data was downloaded from http://www.treas.gov/tic/country-longterm.html, and is also available in the Treasury's monthly bulletin. Across our sample of emerging market countries, only Sri Lanka lacks data from this source.
} 
of firm-specific information. Following Morck, Yeung, and Yu (2000), we compute the proportion of firm-specific volatility from monthly EMDB returns. For each firm, a regression of returns on local index returns is estimated. The r-squared coefficients from such regressions measure how much of the stock's return is due to market-wide influences and, therefore, one minus the r-squared is a measure of the firmspecific volatility. For each window and country, the one minus r-squared for each firm is computed, and a logarithmic transformation converts the figure (which is bounded by zero and one) into a suitable form for subsequent statistical tests. To check robustness, tests involving firm-specific volatility are based on a variety of windows (ranging from 12 to 36 months), data frequencies (weekly and monthly), and currencies (local versus dollar).

Earnings related measures. Additional information environment measures are derived from data surrounding earnings announcements obtained from $\mathrm{I} / \mathrm{B} / \mathrm{E} / \mathrm{S}{ }^{8}{ }^{8}$ The number of analysts counts analysts providing forecasts of the particular earnings event. It proxies for the amount of resources devoted to following the firm. The forecast dispersion is the standard deviation of individual analyst most recent forecasts of a firm's earnings. It is a proxy for pre-announcement uncertainty. The absolute consensus forecast error is the absolute value of the difference between a firm's reported earnings and the median of most recent analyst forecasts for that earnings release. It is a proxy for forecast precision. All forecast variables are scaled by the absolute value of median forecasts. We also scale the forecast variables using the stock price, and the results are qualitatively similar.

For two final measures of the information environment, we combine earnings announcement related data from I/B/E/S and daily returns and trading volumes from Datastream. First, we estimate the absolute value of the abnormal return (computed from the market model) cumulated over a three-day period (day $-1,0$ and 1). Large values of the resulting cumulative absolute abnormal return suggest that earnings are less predictable and more informative (Lang, Lins, and Miller 2003). We also estimate cumulative abnormal trading volume, mean-adjusted over the same three-day period. While returns

\footnotetext{
${ }^{8}$ The Institutional Brokers Estimate System (I/B/E/S) is a service of Thomson Financial and its data have been provided as part of a broad academic program to encourage earnings expectations research.
} 
represent the consensus change in stock value, trading volumes represent differences in opinion. Both absolute abnormal returns and abnormal trading volumes are employed in subsequent difference-in-means and regression tests to understand its behavior as openness to capital flows changes. We used a variety of windows to cumulate abnormal return volatility and abnormal trading volume, and our results appear robust to the choice of window.

We also employ the cumulative abnormal trading volume in regressions to estimate disagreement among traders following Bailey, Li, Mao, and Zhong (2003). We regress cumulative meanadjusted trading volume on firm size (a proxy for the amount of information available about the firm), forecast dispersion (a proxy for pre-announcement information asymmetry), and the event period abnormal absolute return generated. For simplicity, we adopt a linear and additive specification of the regression model following Bamber, Barron, and Stober (1997, 1999). In the model of Kim and Verrecchia (1997), trading volume at the earnings announcement is positively related to the absolute value of the contemporaneous price reaction, pre-announcement differential informedness, and eventperiod private information (or differential informed judgment). In our regression specification to explain abnormal volume, we control for absolute return (which reflects the change in aggregate market expectation at the time of the earnings shock) and pre-announcement differential informedness with the size and forecast dispersion. What remains is trading volume generated by differential informed judgment (or difference in opinions), and it is reflected in the regression intercept. This estimate of "disagreement" around earnings releases is our final information environment indicator. Again, the trade-off between greater precision and greater disagreement as a result of an enhanced information environment could cause either decreases or increases in our disagreement measure with greater openness.

\section{Empirical results}

We have several measures of the information environment: firm-specific return volatility, number of analysts, forecast dispersion, forecast error, and abnormal market responses to earnings. We have three types of measures of openness: dates of liberalization, cross listings, closed end country fund listings, and breakpoints in net portfolio flows; the fraction of capitalization available to foreigners; and the flow of 
portfolio capital to and from the U.S. In this section, we report results of a variety of tests relating changes in openness to changes in the information environment.

\subsection{Summary statistics}

Table 2 contains univariate summary statistics (mean, median, standard deviation, nobs) on the country openness measures and firm-specific volatility (Panel A) and the earnings-related information variables (Panel B). Because investibility and portfolio flow are available monthly, we compute their summary statistics using monthly data. In contrast, the firm-specific volatility is generated with regressions and, for this table, is produced annually. Furthermore, earnings-related information variables are available only once per firm-year so their summary statistics are computed on annual observations.

A number of interesting facts emerge from Panel A. First, median investibility, the fraction of market capitalization available to foreign investors, ranges from almost 100\% (Argentina, Turkey, Poland, South Africa) to much lower levels for several countries (China, India, Korea, Taiwan) with a history of substantial foreign ownership restrictions. ${ }^{9}$ Substantial cross sectional and time variation in investibility enhances the usefulness of this variable in subsequent tests. Second, total U.S. portfolio flow identifies the countries (Argentina, Brazil, Korea, Malaysia, Mexico) that appear to be the dominant targets of U.S. equity portfolio investment. Taiwan is a particularly interesting case as it features low investibility but high U.S. equity portfolio flows. Aside from indicating how popular the country has been with U.S. investors in spite of investment restrictions, this also shows that investibility and portfolio flows are not exactly the same. As we shall see subsequently, it is valuable to employ both variables to reflect different facets of "openness", thereby picking up different facets of the impact of openness on the information environment. Third, there is substantial variation in mean and median firm-specific volatility across countries. This confirms that the information environment, in the form of the degree of firm specific as against market wide information, differs widely across our sample countries, again suggesting that the variable can support meaningful tests.

\footnotetext{
${ }^{9}$ See Bailey, Chung, and Kang $(1996,1999)$ and Jithendranathan, Nirmalanandan, and Tandon (2000) on foreign ownership restrictions in these countries.
} 
Panel B focuses on the information environment measures derived from earnings announcement related data. Two notable facts emerge. First, the median number of analysts per firm ranges widely, from 3 for Venezuela to 20 for Malaysia. The relatively developed Korean market features a median of only 7 analysts per firm. Thus, there is great variation in this variable across countries, and the variable is less than perfectly correlated with the state of economic development (Korea, for example, is far richer and more developed than Venezuela and Malaysia). Second, the Russian market displays the highest levels of absolute forecast error and forecast dispersion, as might be expected of a relatively young market in an underdeveloped legal and disclosure environment. Again, this suggests a rich variety of countries in the sample, and indicates that data problems do not entirely exclude volatile and interesting markets that have only recently emerged.

Table 3 displays non-parametric and parametric cross correlations between and among the information variables, openness variables, and some firm characteristics. This provides an initial look at the strength of associations between the information and openness variables, and the degree of commonality among the information or openness variables. For the purpose of computing these correlations, the openness measures (investibility and gross U.S. portfolio flow) are yearly averages of monthly observations while the information measures (firm-specific volatility, earnings-related variables) are medians across all firms within a country-year.

Some highlights from among the non-parametric correlations are as follows. First, return volatility at earnings release shows strong positive correlation with most other information variables (number of analysts, forecast error and dispersion, abnormal volume). This suggests some commonality across some of our information environment measures. Second, firm-specific volatility is uncorrelated with the other information environment measures that are derived from earnings data. This may be due to the small sample size for earnings-related variables: we have only 160 annual country observations (after pooling across countries and years) in the correlation tables. Firm-specific volatility and earnings-related variables can also reflect different aspects of the firm's information environment. For example, firmspecific volatility can represent overall information production about the firm while our earnings-related 
measures relate more directly to earnings information. We shall see more evidence that the information variables are not identical in subsequent tests.

Second, there is evidence of associations between our openness variables and our information variables. For example, U.S. gross portfolio flows are significantly correlated with number of analysts, forecast dispersion, and return volatility. Investibility is correlated with the number of analysts and forecast dispersion. Third, there are some sensible associations between some of the variables. For example, the number of firms and, in particular, market capitalization is positively correlated with some of the earnings-based information variables. We would expect relatively large emerging markets to draw more attention. Fourth, we see some commonality across our time series measures of openness: investibility is very strongly correlated with U.S. gross equity portfolio flows. There are also associations that are difficult to explain. Investibility is strongly negatively correlated with number of firms and market capitalization. This may reflect the presence of a few economies (notably India and Korea) with relatively large markets but a history of substantial foreign ownership restrictions. Finally, the parametric correlations (Panel B) sometimes mirror the non-parametric correlations but are typically much weaker, indicating the presence of outliers.

\section{2 "Before versus after" tests}

Our sample of explicit (liberalization, cross listing, and country fund) and implicit (estimated portfolio flow breakpoints) events imply distinct "before" and "after" periods. Therefore, we compute difference-in-means tests for changes in firm-specific return volatility and our earnings-related information measures. We also use "before" and "after" dummy variables in regressions. Checks for robustness are detailed in the following discussions. For example, our earnings-related data is relatively constrained in that it does not extend as far back in time as some of our other data and events. Therefore, we repeat certain tests over a reduced sample of time, events, and countries common to more than one test to assess whether differences in data availability substantially affect our results. We also test whether outliers in earnings-related variables bias our results: we confirm all results with critical variables winsorized at the $1 \%$ and $99 \%$ levels. 
Table 4 presents difference in means tests, with two types of information variable (firm-specific volatility, earnings related variables) related to several sets of events (official events, listing events, breakpoints, de-liberalization events). The difference-in-mean statistics are estimated by pooling all firms within a country and all countries in the sample. Some highlights of Panel A, which covers both earnings related measures and firm-specific volatility, are as follows.

First, the set of "feasible official liberalization" events is associated with significant increases in all information variables except abnormal trading volume around earnings announcements. This is confirmed in the "feasible official liberalization" tests conducted over matched pairs of data from the same firm. A "matched pairs" comparison constrains the firms and earnings events included in a test to be balanced before and after the actual event with a "matched pairs" approach. In order for a particular "before" firm-event to be included in the sample, there must be a corresponding event for that firm occurring after the liberalization event. Other firm-events are included in the "all possible data" sample only.

Second, the cross listing and closed-end country fund listing events are even more strongly associated with increases in all earnings-related information measures and the firm-specific volatility information measure. Thus, there is strong evidence in Panel A that official liberalizations and crosslistings of local securities are associated with increases in number of analysts, forecast errors, forecast dispersion, abnormal returns around earnings, and firm specific volatility. This evidence is consistent with our predictions $\mathrm{H} 1$ through H5. There is also marginal evidence that de-liberalization events are associated with declines in the number of analysts and strong evidence of declines in firm-specific volatility. "Before versus after" tests over the de-liberalization events are important for at least two reasons. We predict decreases in proxies for the quality of the information environment at times of deliberalization if our notion that openness and information environment are correlated is true. Furthermore, these special events help distinguish our story from one of fads, noise trading, and other behaviors. If, for example, apparent increases in information environment measures at times of increased 
openness merely reflect time trends in market behavior, we should not observe decreases in information environment measures at times of decreases in openness.

On balance, these findings are consistent with $\mathrm{H} 1$ and $\mathrm{H} 4$, although the evidence on deliberalizations and other information variables is either insignificant or contradictory. In short, Panel A demonstrates that liberalization events are associated with increases in information measures as we predicted, while de-liberalization events are, in some cases, associated with decreases..

Panel B focuses on sets of events for which earnings-related data is sparse and, therefore, presents results only on the firm-specific volatility. The evidence on firm-specific volatility and this expanded set of events confirms our earlier findings. There is strong evidence that the firm-specific volatility increases over these events, and this finding is robust to variations on our tests including matched pairs, common dollar returns variations, and firm-specific volatility computed over weekly, rather than monthly, returns, and also holds over an expanded set of portfolio flow growth rate breakpoints.

To control for potential country-specific and time trend effects on our information variables, we also conduct regression tests, with information variables regressed on "before" and "after" dummy variables for the sets of events described previously, plus terms for country fixed effects (perhaps reflecting country characteristics as used by Morck, Yeung, and Yu, 2000) and calendar year. As is the case for the difference-in-means tests presented previously, these regressions are estimated by pooling all firms within a country and all countries in the sample.

The results are presented in Table 5. In Panel A, the dependent variable is the individual firm annual firm-specific volatility. Estimated coefficients on "Official events - before" and "Breakpoint before" are all negative and significant. It indicates that firm-specific volatility is generally lower prior to liberalization events. Coefficients on "Listing events - after", and "Breakpoint - after" are all positive and highly significant, indicating that firm-specific volatility increases after these increasing openness events occur. The table also reports an F-test that slopes on "before" and "after" dummies are equal (or jointly equal in regression 5), and in three specifications (listing events, breakpoints, and all sets of events included) this is strongly rejected. These results suggest that firm-specific volatility increases significantly 
after various liberalization events. Given the magnitude of coefficients and F-tests, listing events and breakpoint events seem equally important and powerful, in contrast to the results reported in the previous table. However, there is no significant evidence of an impact of "de-liberalization" on firm-specific volatility perhaps due to the fixed country and time effects that are not controlled in the previous table.

In Panel B of Table 5, the dependent variables are the individual firm earnings-related measures of the information environment. For "feasible liberalization" events, coefficients on the "after" dummies are all positive and significant, while coefficients on the "before" dummies are negative or insignificantly positive. F-tests confirm that equality of "before" and "after" dummy coefficients is strongly rejected, except for abnormal trading volume. These results indicate that all earnings-related variables, except abnormal trading volume, increase significantly after liberalization. For de-liberalizations, there is little significant evidence except that abnormal trading volume appears less negative after de-liberalization. Unreported F-tests cannot reject the hypothesis that coefficients on "before" and "after" de-liberalization event dummies are equal.

Other (unreported) results indicate that Panel A results on firm-specific volatility hold up when they are estimated over the smaller set of "feasible" events studied in Panel B. On balance, these pooled regressions confirm the difference-in-mean tests in the previous table. They also give us a sense of which type of liberalization or openness event is most important. That is, we can compare the magnitude of information variable responses around various types of events. It appears that it is not just official announcements that related to changes in the information environment. Breakpoint and listing events seem even more important, which underscores the importance of actual investments by foreign investors. This also reminds us that it is useful to study a variety of indicators of changes in openness.

Table 6 contains results of "disagreement" regression tests in which cumulative abnormal trading volume around earnings events is regressed on variables designed to decompose types of information (as in Bailey, Li, Mao, and Zhong 2003) and dummies for several sets of events (as above). As explained previously, this regression picks up different aspects of trading with control variables, and "disagreement" 
is measured as the residual factor reflected in the constant term and intercept dummies. Fixed effects terms control for country and time.

The regression demonstrates strongly significantly positive coefficients on the "feasible events after" term, and positive but insignificant coefficients on the "feasible events - before" term. However, Ftests indicate that the difference between "before" and "after" coefficients is, at best, marginally significant, It suggests that while there is some evidence of increase in "disagreement" component of trading volume around earnings releases after liberalization events, the change is not statistically significant. Furthermore, "de-liberalization - after" terms are more negative than "de-liberalization before" term, indicating that "disagreement" decreases after de-liberalization. However, F-tests indicate that the difference between "before" and "after" coefficients is, at best, marginally significant.

\subsection{Regressions relating information environment to time-series openness measures}

Recall that our second and third openness measures, the proportion of market cap available to foreigners and the flow of capital between the U.S. and a particular country, are monthly time series. While the previously described "before and after" tests include structural breakpoints in net portfolio flows as "events", we can also use the investibility and portfolio flow variables as ordinary time-series explanatory variables in regressions. Thus, our second set of tests is based on regressing time-series of our information variables on time-series of our "investibility" and "U.S. portfolio flow" series. Given the potential dearth of data for any given country or firm, we pool data across firms and countries. Specifically, the median value of a particular information variable is computed across all sample firms of a given country in a given year, yielding one panel of annual observations for each country. This dependent variable is, in turn, regressed on the "investibility" or U.S. portfolio flow growth matching the country-year. ${ }^{10}$ Other variables are added to control for potential confounding effects and trends. For example, the number of sample firms and their market capitalization per country-year may correct for potential bias in the median firm-specific volatility.

\footnotetext{
${ }^{10}$ Although the median firm-specific volatility is generated at the previous stage, this does not imply an errors-invariables problem in this regression as the firm-specific volatility is the dependent variable.
} 
Table 7 reports pooled time-series cross-sectional regressions of median annual firm-specific volatility per country on (contemporaneous and lagged) investibility and gross portfolio flow per country. Lags are included because the impact of changes in "openness" on the information environment may be gradual, not contemporaneous. The necessity of running regressions with annual medians, as described previously, may facilitate this: one lag of an openness variable provides a window of a year for gradual responses of information variable. The specifications that include investibility as an independent variable $(1,2,3)$ do not show statistically significant slopes on that openness measure. In contrast, positive or marginally positive slopes on lagged portfolio flow in two of three specifications $(5,6)$ indicate that firmspecific volatility eventually responds positively to increased U.S. equity flows to and from a country. Across all six specifications, a number of significantly positive slopes on number of firms and market capitalization suggest that firm-specific volatility tends to be larger in larger markets.

Table 8 reports comparable regressions with the earnings-related-based information variables (number of analysts, forecast dispersion, forecast error, cumulative abnormal absolute return, and cumulative abnormal trading volume) as dependent variables. In Panel A, the (contemporaneous and lagged) investibility measure of openness is the principal explanatory variable. Absolute forecast error, forecast dispersion, and abnormal return volatility around earnings are strongly positively correlated with both contemporaneous and lagged investibility. This indicates that increased availability of a country's equities to foreigners is associated with substantial changes in the information environment. Among the control variables, it is interesting to see that the number of analysts is negatively correlated with the number of firms in a country. The result is robust given the use of winsorized series throughout the paper. It may reflect the presence of a few countries with a relatively small number of firms but relatively large number of analysts per firm (Argentina, Brazil) and countries with a relatively large number of firms but a relatively small number of analysts per firm (Korea), as indicated in Table 2, Panel B. In contrast, larger market cap is sensibly associated with a larger number of analysts.

In Panel B the (contemporaneous and lagged) gross equity portfolio flow measure of openness is the principal explanatory variable. There is evidence that the number of analysts, absolute forecast error, 
and forecast dispersion increase as the amount of U.S. equity investment flowing across a country's borders increases. Interestingly, a larger number of listed firms in a given country is associated with fewer analysts but larger forecast errors, forecast dispersion, and absolute return volatility. Larger market capitalization is associated with more analysts, smaller forecast errors and forecast dispersion, greater absolute return volatility, and lower abnormal trading volume. There is some evidence of multicolinearity in comparing results across the panels. For example, forecast dispersion is negatively and insignificantly related to the number of firms in Panel A while in Panel B it is significantly positively correlated. This may relate to the complex pattern of correlations among forecast dispersion, the number of firms, and the two openness measures, investibility and portfolio flow, evident in Table 3.

Once again, somewhat different results emerge for firm-specific volatility versus our earningsrelated-based variables. In particular, lagged "openness" is more important for firm-specific volatility while contemporaneous "openness" is more important for the earnings-related variables. It may be the case that, upon becoming more open to foreign investment, an emerging market quickly draws foreign attention to immediate, specific earnings events while coverage of a more general nature takes time to develop. At a minimum, it confirms that the use of several dimensions of the information environment is valuable for understanding different dimensions of the relationship between openness to foreign investment and information production.

\subsection{A closer look at a cross section of individual firms from one country}

Our tests to this point largely feature variables that have been aggregated across firms and months within a year. For example, we use country medians of individual firm-specific volatility over a calendar year, rather than the individual firm specific-volatilities over shorter time periods. While this aggregation has many advantages, it also limits our ability to control for individual firm characteristics when we relate information variables to indicators of liberalization or openness to foreign portfolio investment. For example, it may be the case that increased openness elicits more information production for smaller firms that foreign investors target once they are allowed into the market. Alternatively, apparent associations 
between measures of the information environment and openness may be driven by firm size or other characteristics that are lost when we aggregate individual firm data into country medians.

To address these concerns, we produce additional results for a cross section of individual firms from Korea. The Korean market has several characteristics that make it particularly suited to our investigation. First, there has been a significant change in foreign equity investment restrictions, which allows us to detect the impact of foreign equity investment with relative ease. In some respects, Korea was early in opening to foreign equity investors: Appendix 1 indicates that the first Korean closed end fund was listed in the U.S. in 1984 while Bailey, Chung, and Kang (1996) describe the introduction of convertible eurobonds by Korean issuers. On the other hand, direct access by foreigners to the Korean stock market was permitted in a very limited way in January 1992 while substantial foreign ownership was achieved only gradually with a series of liberalization events in the mid and late 1990s.

Second, the Korean market is a major target of foreign portfolio investors, ranking third among our sample countries in terms of U.S. portfolio investment. Third, detailed firm-level data are easily available. In addition to stock returns and financial statements data, a substantial variety of governancerelated variables such as foreign ownership and business group affiliation are available. These governance-related variables can affect the firm's information environment and have been extensively used by many researchers. See, for example, Bae, Kang, and Kim (2002), Baek, Kang, and Park (2003), and Joh (2003). Specifically, we use the Korea Securities Research Institute (KSRI) database for stock returns and the Listed Company Database of the Korean Listed Companies Association for financial statements and ownership information. In Korea, a large business group is typically referred to as a chaebol, and membership of such a group is thought to have substantial (and negative) implications for governance and performance (Bae, Kang, and Kim 2002). ${ }^{11}$

To study individual Korean firms, we parallel Tables 7 and 8 (based on country median data) and run regressions of individual firm volatility on openness variables and firm characteristics. From all

\footnotetext{
${ }^{11}$ The Korea Fair Trade Commission (KFTC) defines a business group as "a group of companies of which more than 30 percent of shares are owned by the group's controlling shareholder and its affiliated companies." Each year the KFTC identifies the 30 largest chaebol groups.
} 
Korean firms listed during 1987 to 2001, we select non-financial firms with fiscal year ending in December. This yields approximately 400 to 500 firms for each sample year. For each firm-year, we compute firm-specific volatility and the following firm-specific characteristic variables: the log of market cap, cash flow (operating income plus depreciation divided by total assets), the fraction of total assets invested in affiliated firms, a dummy variable for membership in a chaebol business group, and the fraction of total equity held by foreign investors. These data are then merged with the annual portfolio flow and investibility measures.

Table 9 reports pooled time series cross sectional regressions of individual firm-specific volatility by year on (contemporaneous and lagged) annual investibility and gross portfolio flow. Individual firm characteristics are included as control variables to assess whether the apparent relationship between individual firm information environment and openness is due to other factors.

The results in Table 9 are consistent with our predictions and with our earlier results on aggregated variables. The individual firm specific volatility is very strongly positively correlated with the lagged investibility measure and the contemporaneous and lagged portfolio flow measure. That is, firm specific information is strongly related to, and probably preceded by, increased openness to foreign portfolio investors. In addition to this insight regarding our fundamental question of openness and information environment, there are also interesting associations between firm specific volatility and firm characteristics. Larger firms tend to have smaller firm-specific volatility. Firms that have a larger concentration of assets in the shares of affiliated firms or firms that are associated with a chaebol group tend to have lower firm-specific volatility. This is sensible: previous authors have shown that such firms are more likely to suffer from relatively poor governance and disclosure. In contrast, firms with more foreign ownership tend to have higher firm-specific volatility, which is consistent with greater scrutiny from foreign owners.

Table 10 presents comparable pooled time series cross sectional regressions of individual firm earnings-related measures (number of analysts, forecast dispersion, forecast error, cumulative abnormal absolute return, and so on) by year on investibility and gross portfolio flow per country. 
[Conclude by talking about the links between governance and information environment.]

\subsection{In which direction does causality run?}

Our earlier work shows that information variables often relate to contemporaneous and lagged values of our two time-series openness measures, investibility and total U.S. portfolio flow. These results are consistent with our notion that increased openness to foreign equity portfolio investment elicits increases in the production and processing of information. This interpretation implies that liberalization and other acts of increasing access have a beneficial effect on the information environment, in addition to the decreased cost of capital documented by previous authors.

However, it may be the case that openness is a consequence of changes in the information environment, rather than triggering changes in the information environment as we theorize. As more information about firms in an emerging market becomes available, foreign demand for local stocks increases and puts pressure on local authorities to loosen access. A good example might be the "official liberalization" by Thailand in the form of creating an explicit "Alien Board" for trading of shares that had hit foreign ownership limits. Previously, foreigners had access to Thai equities to a point but, once the legal limit on foreigners was reached for a specific company, foreigners could no longer trade in the market. See Bailey and Jagtiani (1994). Interest in Thailand's high rate of economic growth and profitable companies may have preceded the actual loosening of access. At an extreme, we might imagine that brokerage firms, analysts, and other market participants with an interest in increased market activity produce more information and excite foreign investor interest, eventually precipitating a loosening of capital barriers. On the other hand, investment in information production (such as the number of analysts) may precede increases in openness because the capital market begins to invest in more information production in anticipation of a more open capital market.

To test for such effects, Table 11 reports tests that stack a pair of variables, an information variable and an openness variable, in a VAR to determine the lead-lag associations. 
The table reports p-values from Wald tests on the joint significance of the coefficients that govern the lead of openness over information (reflecting our notion that openness elicits further information production and processing), and additional Wald tests for information triggering openness. Clear evidence of our hypothesis is observed for firm-specific volatility and portfolio flow: the coefficients for openness leading information are marginally significant while the coefficients for information leading openness are insignificant. In contrast, the causality between number of analysts and portfolio flow is bi-directional, with stronger causality from number of analysts to portfolio flow. There is also evidence that causality runs from two other information variables, forecast error and forecast dispersion, to the investibility measure of openness. Other associations are largely insignificant. Thus, we find some evidence that causality is more likely to run from openness to information environment as we predict, although the evidence is weak and somewhat mixed.

\section{Summary and conclusions}

We have uncovered interesting associations between the state of the information environment and the degree of openness to foreign equity investment across a sample of emerging markets.

First, official liberalization events are associated with increases in firm-specific volatility and most earnings-related-based proxies for the information environment. The impact of individual firms cross listing of shares overseas or the listing of a closed-end country fund is even stronger. These events have a significant impact on the information environment in an emerging stock market. Second, the response of information environment proxies to de-liberalization events that restrict foreign access is sometimes opposite in sign to the response to liberalization events. When foreign equity investment is impeded, many aspects of the information environment recede. Third, increased openness leads to increases in "disagreement" or "difference of opinion" among investors. That is, openness to foreign equity investment tends to foment more disagreement and struggle among traders around earnings announcements. Fourth, the firm-specific volatility facet of the information environment responds to one time-series measure of openness, the gross portfolio, only with a lag, suggesting that information production and processing trail U.S. portfolio investment flows into a country. In contrast, most of our 
earnings-related-based measures of the information environment respond to contemporaneous (and, in some cases, lagged as well) investibility or portfolio flow. This suggests that different facets of the information environment respond differently to changes in the degree of openness and the actual extent of foreign equity flows across an emerging economy's borders. Fifth, results on individual Korean firms confirm the impact of increased openness on the information environment, and also indicate the importance of governance proxies for changes in the information environment. Finally, causality appears to run from openness to information environment as we predict, although there is some evidence that the number of analysts rises prior to an increase in openness.

Clearly, liberalization and other acts of opening to foreign equity investors have an impact on the information environment. Thus, we have succeeded in documenting another facet of the impact of the transition of emerging stock markets to integration with the global capital market. Opening to foreign portfolio investors does not just lower the cost of capital but also alters the local environment for disclosure, other information production, and the analysis and use of that information. However, questions remain. Are increases in an information environment measure necessarily beneficial to an emerging economy? For example, an increase in absolute forecast errors and abnormal market responses may indicate that openness prompts firms to release more accurate, timely indicators of their profitability that are more informative and, therefore, evoke a larger market response. An increase in preannouncement forecast dispersion may indicate that there are more analysts grappling with greater quantity and quality of information. However, such increases may also indicate that, upon opening further to foreigners, markets suffer more confusion, information overload, and noise trading. 


\section{References}

Admati, Anat R., and Paul Pfleiderer, 2000, Forcing Firms to Talk: Financial Disclosure and Externalities, Review of Financial Studies 13, 479-520.

Alexander, Gordon, Eun, Cheol, and S. Janakiramanan, 1987, Asset Pricing and Dual Listing on Foreign Capital Markets: A Note, Journal of Finance 42, 151-158.

Bae, Kee-Hong, Chan, Kalok, and Angela Ng, 2002, Investibility and Return Volatility, Journal of Financial Economics, forthcoming.

Bae, Kee-Hong, Kang, Jun-Koo, and Jin-Mo Kim, 2002, Tunneling or Value Added: Evidence from Mergers by Korean Business Groups, Journal of Finance, 2695-2740.

Baek, Jae-Seung, Kang, Jun-Koo, and Kyung Suh Park, 2003, Corporate Governance and Firm Value: Evidence from the Korean Financial Crisis, Journal of Financial Economics, forthcoming.

Bailey, Warren, Chung, Peter, and Jun-koo Kang, 1996, Investment Restrictions and the Pricing of Korean Convertible Eurobonds, Pacific Basin Finance Journal 4, 93-111.

Bailey, Warren, Chung, Peter, and Jun-koo Kang, 1999, Foreign Ownership Restrictions and Equity Price Premiums: What Drives the Demand for Cross-Border Investments?, Journal of Financial and Quantitative Analysis 34, 489-512.

Bailey, Warren, and Julapa Jagtiani, 1994, Foreign Ownership Restrictions and Stock Prices in the Thai Capital Market, Journal of Financial Economics 36, 57-87.

Bailey, Warren, Karolyi, G. Andrew, and Carolina Salva, 2002, The economic consequences of increased disclosure: Evidence from international cross-listings, unpublished Cornell University, Ohio State University, and Instituto de Empresa working paper.

Bailey, Warren, Li, Haitao, Mao, Connie X., and Rui Zhong, 2003, Regulation Fair Disclosure and Earnings Information: Market, Analyst, and Corporate Responses, forthcoming, Journal of Finance. 
Baker, W. Kent, John R. Nofsinger, and Daniel P. Weaver, 2002, International Cross-listing and Visibility, Journal of Financial and Quantitative Analysis 37, 495 - 521.

Ball, Ray, Kothari, S. P, and A. Robin, 2000, An Extension of the Effect of International Institutional Factors on the Properties of Accounting Earnings, Journal of Accounting and Economics 29, 151.

Bekaert, Geert, and Campbell R. Harvey, 1995, Time-varying world market integration, Journal of Finance 50, 403-444.

Bekaert, Geert, and Campbell R. Harvey, 2000, Foreign speculators and emerging equity markets, Journal of Finance 55, 565-613.

Bekaert, Geert, Harvey, Campbell R., and Robin L. Lumsdaine, 2002, Dating the integration of world equity markets, Journal of Financial Economics 65, 203-248.

Bekaert, Geert, and Michael S. Urias, 1996, Diversification, Integration, and Emerging Market ClosedEnd Funds, Journal of Finance 51, 835-870.

Bekaert, Geert, Harvey, Campbell R., and Christian Lundblad, 2002, Growth Volatility and Equity Market Liberalization, unpublished Duke University working paper (July).

Bekaert, Geert, Harvey, Campbell R., and Christian Lundblad, 2003, Equity Market Liberalization in Emerging Markets, unpublished Duke University working paper (January).

Cantale, Salvatore, 1996, The choice of a foreign market as a signal, unpublished Tulane University working paper.

Chan, Kalok, and Allaudeen S. Hameed, 2002, Stock Price Synchronicity and Analyst Coverage in Emerging Markets, unpublished Hong Kong University of Science and Technology and National University of Singapore working paper (December).

Chari, Anusha, and Peter Blair Henry, 2002, Capital account liberalization: Allocative efficiency or animal spirits?, unpublished Stanford University working paper (April).

Choe, Hyuk, Kho, Bong-Chan, and Rene M. Stulz, 1999, Do Foreign Investors Destabilize Stock Markets? The Korean experience in 1997, Journal of Financial Economics 54, 227-264. 
Doidge, Craig, 2003, U.S. Cross-listings and the Private Benefits of Control: Evidence from Dual-Class Firms, Journal of Financial Economics, forthcoming.

Durnev, Artyom, Morck, Randall, and Bernard Yeung, 2001, Capital Markets and Capital Allocation: Implications for Economies in Transition, unpublished New York University working paper.

Durnev, Artyom, Morck, Randall, and Bernard Yeung, 2003, Value-Enhancing Capital Budgeting and Firm-Specific Stock Return Variation, forthcoming, Journal of Finance.

Durnev, Artyom, Morck, Randall, Yeung, Bernard, and Paul Zarowin, 2003, Does Greater Firm-Specific Return Variation Mean More or Less Informed Stock Pricing?, Journal of Accounting and Economics, forthcoming.

Edison, Hali J., and Francis E. Warnock, 2001, A Simple Measure of the Intensity of Capital Controls, unpublished International Monetary Fund working paper (September).

Errunza, Vihang, and Etienne Losq, 1985, International Asset Pricing under Mild Segmentation: Theory and Tests, Journal of Finance 40, 105-124.

Foerster, Stephen R., and G. Andrew Karolyi, 1999, The effects of market segmentation and illiquidity on asset prices: Evidence from foreign stocks listing in the U.S., Journal of Finance 54, 981-1013.

Froot, Kenneth A., O’Connell, Paul G. J., and Mark S. Seasholes, 2001, The Portfolio Flows of International Investors, Journal of Financial Economics 59, 151-194.

Fuerst, Oren, 1998, A Theoretical Analysis of the Investor Protection Regulations Argument for Global Listing of Stocks, unpublished Yale University working paper.

Henry, Peter Blair, 2000, Stock market liberalization, economic reform, and emerging market equity prices, Journal of Finance 55, 529-564.

Holthausen, Robert W., and Robert E. Verrecchia, 1990, The Effect of Informedness and Consensus on Price and Volume Behavior, The Accounting Review 65, 191-208.

Huddart, Steven, John S. Hughes and Markus Brunnermeier, 1999, Disclosure Requirements And Stock Exchange Listing Choice In An International Context, Journal of Accounting and Economics 26, 237-269. 
Jithendranathan, T., Nirmalanandan, T. R., and K. Tandon, 2000, Barriers to International Investing and Market Segmentation: Evidence from Indian GDR Market, Pacific Basin Finance Journal 8, 399418.

Joh, Sung-Wook, 2003, Corporate governance and firm profitability: Evidence from Korea before the economic crisis, Journal of Financial Economics 68, 287-322.

Kaminsky, Graciela L., and Sergio Schmukler, 2002, Short Run Pain, Long Run Gain: The Effects of Financial Liberalization, unpublished George Washington University and World Bank working paper (June).

Kandel, Eugene, and Neil D. Pearson, 1995, Differential interpretation of public signals and trade in speculative markets, Journal of Political Economy 103, 831-872.

Karolyi, G. Andrew, Morck, Randall, Stulz, Rene, and Bernard Yeung, Firm-Specific Stock Return Variation Around International Cross-Listings, work in progress.

Karpoff, Jonathan M., 1986, A theory of trading volume, Journal of Finance 41, 1069-1087.

Karpoff, Jonathan M., 1987, The relation between price changes and trading volume: A survey, Journal of Financial and Quantitative Analysis 22, 109-126.

Kim, E. Han, and Vijay Singal, 2000, Stock Market Openings: Experience of Emerging Economies, Journal of Business 73, 25-66.

Kim, Oliver, and Robert E. Verrecchia, 1994, Market liquidity and volume around earnings announcements, Journal of Accounting and Economics 17, 41-67.

Kim, Oliver, and Robert E. Verrecchia, 1997, Pre-announcement and event period private information, Journal of Accounting and Economics 24, 395-419.

Krugman, Paul, 1998, Saving Asia: It's Time to Get Radical, Fortune, $7^{\text {th }}$ September, 74-80.

Lang, Mark H., Lins, Karl V., and Darius Miller, 2003, ADRs, Analysts, and Accuracy: Does Cross Listing in the U.S. Improve a Firm's Information Environment and Increase Market Value?, Journal of Accounting Research 41, 317-346. 
Lang, Mark H., Raedy, J.S., and M. H. Yetman, 2003, How Representative are Firms that Cross-Listed? An Analysis of Accounting Quality, Journal of Accounting Research 41, 363-386.

Leuz, Christian, 2003, Discussion of ADRs, Analysts, and Accuracy: Does Cross Listing in the U.S. Improve a Firm's Information Environment and Increase Market Value?, Journal of Accounting Research 41, 347-362.

Leuz, Christian, Nanda, Dhananjay, and Peter D. Wysocki, 2003, Earnings Management and Investor Protection: An International Comparison, Journal of Financial Economics 69, 505-528.

Miller, Darius P., 1999, The market reaction to international cross-listings: Evidence from Depositary Receipts, Journal of Financial Economics 51, 103-123

Moel, Alberto, 1998, The Role of Information Disclosure on Stock Market Listing Decisions, unpublished Harvard University working paper.

Morck, Randall, Yeung, Bernard, and Wayne Yu, 2000, The information content of stock markets: Why do emerging markets have synchronous stock price movements?, Journal of Financial Economics $58,215-260$.

Obstfeld, Maurice, 1998, The Global Capital Market: Benefactor or Menace?, Journal of Economic Perspectives 12, 9-30.

Patro, Dilip, 2002, Stock Market Liberalization and Emerging Market Country Fund Premiums, unpublished Rutgers University working paper.

Roll, Richard W., 1988, R², Journal of Finance 43, 541-566.

Rouwenhorst, Geert, 1999, Local return factors and turnover in emerging stock markets, Journal of Finance 54, 1439-1464.

Skinner, D., 1994, Why Firms Voluntarily Disclose Bad News, Journal of Accounting Research 32, 3861.

Stulz, Rene M., 1999, Globalization of Capital Markets and the Cost of Capital, Journal of Applied Corporate Finance 12, 8-25. 
Stiglitz, Joseph, 1999, Bleak Growth for the Developing World, International Herald Tribune, $6^{\text {th }}$ April, 10-11.

Tandon, Kishore, 1997, External Financing in Emerging Markets: An Analysis of Market Responses, Emerging Markets Quarterly 1, 63-74. 


\section{Table 1. Sequence of liberalizations and changes in openness}

This table presents the sequence of liberalization events. Official liberalization events (I) are from Bekaert and Harvey (2000), and are extended to additional countries we study. When firm returns are not available, an official liberalization event is excluded and a subsequent official liberalization event is substituted if available. Cross-listing or country fund listing event (II) is the first such event after our official liberalization event, if any; else the earliest such event our data covers. If cross-listing or country fund listing date is within a year of our official liberalization event, then the next such event is selected. Estimate of breakpoint of growth rate of net US equity portfolio capital flows (III) is from Bekaert and Harvey (2000). De-liberalization events (IV) increase barriers to investment, rather than lowering them. Given constraints on the time span covered by IBES, earliest feasible liberalization events (V) are earliest events for each country (from (I) or (II) or (III)) for which both pre- and post-liberalization information is available from IBES in addition to Datastream.

\begin{tabular}{|c|c|c|c|c|c|}
\hline & I & II & III & IV & $\mathrm{V}$ \\
\hline Country & $\begin{array}{c}\text { Official } \\
\text { liberalization }\end{array}$ & $\begin{array}{l}\text { Cross-listing or } \\
\text { country fund } \\
\text { listing }\end{array}$ & $\begin{array}{l}\text { Estimate of break } \\
\text { in growth of net } \\
\text { US capital flow }\end{array}$ & $\begin{array}{c}\text { De- } \\
\text { liberalization }\end{array}$ & $\begin{array}{c}\text { Earliest feasible } \\
\text { liberalization }\end{array}$ \\
\hline Argentina & 89.11 & 91.10 & 93.04 & 02.01 & - \\
\hline Brazil & 91.05 & 92.05 & 88.06 & - & 96.10 \\
\hline Chile & 92.01 & - & 88.01 & 95.07 & - \\
\hline China & - & 97.03 & - & - & 97.03 \\
\hline Colombia & 91.02 & 95.07 & 93.08 & - & - \\
\hline Czech Rep & - & 95.07 & - & - & - \\
\hline Greece & 87.12 & 97.06 & 86.12 & - & 97.06 \\
\hline Hungary & 96.01 & 97.11 & - & - & 97.11 \\
\hline India & 92.11 & 99.03 & 93.04 & - & 99.03 \\
\hline Indonesia & - & 94.10 & 93.06 & - & - \\
\hline Korea & 92.01 & 94.10 & 93.03 & - & 92.01 \\
\hline Malaysia & 88.12 & 90.02 & 92.04 & 94.02 & - \\
\hline Mexico & 89.05 & - & 90.05 & - & - \\
\hline Pakistan & 91.02 & 93.12 & 93.04 & - & - \\
\hline Peru & - & 96.05 & - & - & 96.05 \\
\hline Philippines & 91.06 & 00.03 & 90.01 & - & - \\
\hline Poland & - & 97.07 & - & - & 97.07 \\
\hline Portugal & - & 89.11 & 94.08 & - & 95.06 \\
\hline Russia & - & 96.11 & - & 97.05 & - \\
\hline South Africa & - & 94.03 & - & - & - \\
\hline Sri Lanka & 00.01 & - & - & - & - \\
\hline Taiwan & 91.01 & 95.04 & 92.08 & - & - \\
\hline Thailand & 87.09 & - & 88.07 & 97.06 & 92.05 \\
\hline Turkey & 89.08 & 90.08 & 89.12 & 94.06 & - \\
\hline Venezuela & 90.01 & 91.11 & 94.02 & - & - \\
\hline
\end{tabular}




\section{Table 2. Univariate summary statistics}

This table provides summary statistics for two time-series proxies for openness and six proxies for the information environment. The openness proxies are: the proportion of the local market's capitalization that is available to foreign investors at month end and the total flow of equity portfolio investment of U.S. investors in and out of the country per month. The information environment proxies are: firm-specific return volatility following Morck, Yeung, and Yu (2000), the number of analysts providing annual earnings forecasts per firm and per annual earnings release, earnings forecast error (the absolute value of the difference between actual earnings and median forecasts scaled by the absolute median forecast), earnings forecast dispersion (the standard deviation of the most recent individual forecasts scaled by the absolute median forecast), absolute abnormal return around earnings announcement, and abnormal trading volume around earnings announcement. Firm-specific volatility is obtained from a market model run for each firm in each country each year starting from 1987 to 2000. Each regression uses 12 return observations in each year and is not overlapped. Earnings announcement responses are computed as follows. Abnormal returns are computed based on one-factor market model residuals estimated from day -200 to day -11 at annual earnings announcement with value-weighted local stock index returns. Abnormal return volatility is the absolute value of daily abnormal returns, summed over the window of day $(-1,+1)$. Abnormal trading volumes are generated as the differences between trading volume and the mean of daily volume for that stock over the pre-announcement window $(-200,-11)$ normalized by the mean volume, then summing over the window of day $(-1,+1)$. The summary statistics are presented in two panels, one that covers the two openness proxies and the firm-specific volatility

information environment measure and the other for the earnings-related information environment measures. In the table, "nobs" indicates the number of observations available for the variable while "nfirms" indicates the number of distinct firms in the sample. In Panel B, all variables are earnings related, with one observation per firm-year for each variable. The number of observations indicates the number of firm-events and, thus, the number of observations for each variable. 
Table 2, Panel A

\begin{tabular}{|c|c|c|c|c|c|c|c|c|c|c|c|c|c|}
\hline \multirow[t]{2}{*}{ Country } & \multicolumn{4}{|c|}{ Monthly Investibility } & \multicolumn{4}{|c|}{ Monthly Total U.S. portfolio flow } & \multicolumn{5}{|c|}{ Annual Firm-specific volatility } \\
\hline & mean & median & stdev & nobs & mean & median & stdev & nobs & mean & median & stdev & Nobs & nfirms \\
\hline Argentina & 0.950 & 0.982 & 0.059 & 169 & 391 & 323 & 372 & 180 & 0.462 & 0.436 & 0.294 & 431 & 47 \\
\hline Brazil & 0.681 & 0.733 & 0.262 & 169 & 1316 & 822 & 1379 & 180 & 0.628 & 0.641 & 0.268 & 1059 & 122 \\
\hline Chile & 0.570 & 0.236 & 0.376 & 169 & 105 & 84 & 106 & 180 & 0.619 & 0.627 & 0.252 & 609 & 67 \\
\hline China & 0.195 & 0.114 & 0.132 & 121 & 45 & 15 & 75 & 180 & 0.566 & 0.566 & 0.282 & 1645 & 296 \\
\hline Colombia & 0.752 & 0.784 & 0.125 & 129 & 18 & 10 & 28 & 180 & 0.606 & 0.612 & 0.285 & 344 & 39 \\
\hline Czech Republic & 0.609 & 0.476 & 0.258 & 109 & 52 & 3 & 167 & 180 & 0.711 & 0.739 & 0.220 & 272 & 74 \\
\hline Greece & 0.909 & 0.938 & 0.101 & 149 & 73 & 29 & 104 & 180 & 0.544 & 0.543 & 0.265 & 502 & 81 \\
\hline Hungary & 0.848 & 0.946 & 0.176 & 121 & 19 & 5 & 34 & 180 & 0.576 & 0.579 & 0.279 & 138 & 27 \\
\hline India & 0.272 & 0.262 & 0.072 & 122 & 116 & 60 & 151 & 180 & 0.612 & 0.618 & 0.239 & 1482 & 189 \\
\hline Indonesia & 0.649 & 0.572 & 0.231 & 148 & 103 & 63 & 122 & 180 & 0.646 & 0.652 & 0.239 & 680 & 144 \\
\hline Korea & 0.484 & 0.221 & 0.390 & 132 & 585 & 335 & 690 & 180 & 0.595 & 0.608 & 0.258 & 1796 & 260 \\
\hline Malaysia & 0.845 & 0.844 & 0.097 & 169 & 268 & 186 & 264 & 180 & 0.482 & 0.449 & 0.236 & 1431 & 216 \\
\hline Mexico & 0.851 & 0.906 & 0.204 & 169 & 1320 & 1251 & 981 & 180 & 0.622 & 0.622 & 0.272 & 886 & 141 \\
\hline Pakistan & 0.627 & 0.760 & 0.250 & 128 & 11 & 3 & 19 & 180 & 0.632 & 0.655 & 0.265 & 851 & 131 \\
\hline Peru & 0.896 & 0.919 & 0.054 & 121 & 52 & 44 & 87 & 180 & 0.639 & 0.682 & 0.258 & 274 & 52 \\
\hline Philippines & 0.472 & 0.471 & 0.034 & 169 & 73 & 60 & 71 & 180 & 0.619 & 0.599 & 0.258 & 598 & 94 \\
\hline Poland & 0.994 & 0.999 & 0.009 & 121 & 23 & 13 & 29 & 180 & 0.541 & 0.546 & 0.256 & 221 & 45 \\
\hline Portugal & 0.739 & 0.778 & 0.133 & 124 & 120 & 48 & 169 & 180 & 0.607 & 0.608 & 0.264 & 267 & 51 \\
\hline Russia & 0.706 & 0.715 & 0.046 & 71 & 61 & 10 & 102 & 180 & 0.571 & 0.580 & 0.281 & 114 & 45 \\
\hline South Africa & 0.991 & 1.000 & 0.015 & 121 & 119 & 96 & 117 & 180 & 0.704 & 0.725 & 0.224 & 607 & 106 \\
\hline Sri Lanka & 0.353 & 0.326 & 0.103 & 107 & - & - & - & - & 0.560 & 0.545 & 0.259 & 411 & 64 \\
\hline Taiwan & 0.285 & 0.327 & 0.217 & 144 & 460 & 83 & 712 & 180 & 0.515 & 0.505 & 0.246 & 1243 & 164 \\
\hline Thailand & 0.385 & 0.310 & 0.123 & 169 & 109 & 68 & 98 & 180 & 0.495 & 0.469 & 0.258 & 760 & 126 \\
\hline Turkey & 0.974 & 0.999 & 0.075 & 161 & 156 & 47 & 288 & 180 & 0.445 & 0.411 & 0.236 & 557 & 83 \\
\hline Venezuela & 0.709 & 0.711 & 0.226 & 142 & 75 & 32 & 165 & 180 & 0.588 & 0.611 & 0.277 & 247 & 29 \\
\hline Average & 0.670 & 0.653 & 0.151 & 138 & 236 & 154 & 264 & 180 & 0.583 & 0.585 & 0.259 & 697 & 108 \\
\hline
\end{tabular}


Table 2, Panel B

\begin{tabular}{|c|c|c|c|c|c|c|c|c|c|c|c|c|c|c|c|c|c|c|}
\hline \multirow[t]{2}{*}{ Country } & \multirow[t]{2}{*}{ nobs } & \multirow[t]{2}{*}{ nfirms } & \multirow{2}{*}{$\begin{array}{l}\text { Data } \\
\text { Starts }\end{array}$} & \multicolumn{3}{|c|}{ Number of analysts } & \multicolumn{3}{|c|}{ Absolute forecast error } & \multicolumn{3}{|c|}{ Forecast dispersion } & \multicolumn{3}{|c|}{ Abnormal return volatility } & \multicolumn{3}{|c|}{ Abnormal trading volume } \\
\hline & & & & mean & median & stdev & mean & Median & stdev & mean & median & stdev & mean & Median & stdev & mean & median & stdev \\
\hline Argentina & 87 & 17 & 199306 & 16.602 & 17 & 9.082 & 1.685 & 0.267 & 7.478 & 1.246 & 0.315 & 3.694 & 0.049 & 0.042 & 0.033 & 0.105 & -0.064 & 0.793 \\
\hline Brazil & 137 & 30 & 199412 & 14.858 & 16 & 10.550 & 8.627 & 0.263 & 92.160 & 5.296 & 0.327 & 5.211 & 0.055 & 0.043 & 0.041 & -0.125 & -0.203 & 0.720 \\
\hline Chile & 98 & 18 & 199212 & 6.322 & 5 & 3.699 & 0.462 & 0.106 & 1.394 & 0.498 & 0.152 & 1.325 & 0.031 & 0.025 & 0.022 & 0.029 & -0.256 & 1.022 \\
\hline China & 91 & 16 & 199212 & 8.295 & 7 & 5.632 & 1.032 & 0.181 & 4.233 & 0.416 & 0.154 & 1.048 & 0.058 & 0.048 & 0.039 & 0.505 & -0.057 & 1.585 \\
\hline Colombia & 2 & 1 & 199412 & 4.000 & 4 & 1.414 & 0.313 & 0.313 & 0.439 & 0.149 & 0.149 & 0.178 & 0.031 & 0.031 & 0.034 & -0.583 & -0.583 & 0.522 \\
\hline Czech Re & 58 & 17 & 199412 & 9.310 & 6 & 7.267 & 1.089 & 0.191 & 3.552 & 0.721 & 0.266 & 1.443 & 0.050 & 0.038 & 0.039 & -0.151 & -0.337 & 0.962 \\
\hline Greece & 343 & 57 & 199212 & 8.757 & 8 & 5.238 & 1.112 & 0.164 & 11.809 & 7.863 & 0.183 & 4.079 & 0.046 & 0.037 & 0.032 & -0.006 & -0.279 & 1.145 \\
\hline Hungary & 55 & 12 & 199412 & 16.034 & 15 & 8.236 & 0.239 & 0.050 & 0.758 & 0.171 & 0.118 & 0.220 & 0.055 & 0.047 & 0.040 & 0.085 & -0.109 & 0.925 \\
\hline India & 176 & 50 & 199512 & 10.814 & 10 & 7.097 & 1.006 & 0.085 & 10.771 & 0.224 & 0.132 & 0.287 & 0.069 & 0.053 & 0.059 & 0.433 & -0.185 & 1.850 \\
\hline Indonesia & 207 & 49 & 199012 & 12.792 & 12 & 7.831 & 1.587 & 0.216 & 5.369 & 3.380 & 0.269 & 39.842 & 0.081 & 0.066 & 0.063 & 0.483 & -0.224 & 2.264 \\
\hline Korea & 752 & 106 & 198806 & 8.240 & 7 & 5.678 & 1.233 & 0.246 & 10.071 & 0.735 & 0.271 & 1.853 & 0.065 & 0.050 & 0.052 & 0.026 & -0.281 & 0.937 \\
\hline Malaysia & 638 & 88 & 198811 & 20.017 & 20 & 11.876 & 0.589 & 0.113 & 2.329 & 0.459 & 0.134 & 1.500 & 0.047 & 0.038 & 0.033 & 0.063 & -0.273 & 1.089 \\
\hline Mexico & 66 & 16 & 199212 & 18.623 & 19 & 7.829 & 0.712 & 0.100 & 1.633 & 6.060 & 0.202 & 32.703 & 0.046 & 0.039 & 0.032 & -0.037 & -0.295 & 0.886 \\
\hline Pakistan & 38 & 21 & 199206 & 5.077 & 5 & 2.057 & 0.411 & 0.146 & 1.138 & 0.369 & 0.168 & 0.539 & 0.058 & 0.047 & 0.046 & 0.369 & -0.311 & 1.938 \\
\hline Peru & 25 & 7 & 199412 & 7.652 & 5 & 5.928 & 0.390 & 0.126 & 0.623 & 0.411 & 0.198 & 0.506 & 0.055 & 0.041 & 0.045 & 0.017 & -0.244 & 1.257 \\
\hline Philippines & 183 & 37 & 199009 & 14.478 & 14 & 8.472 & 1.486 & 0.136 & 4.931 & 0.731 & 0.181 & 2.270 & 0.067 & 0.053 & 0.051 & 0.118 & -0.255 & 1.800 \\
\hline Poland & 60 & 22 & 199512 & 10.871 & 12 & 5.085 & 0.479 & 0.121 & 0.977 & 0.451 & 0.159 & 0.752 & 0.058 & 0.045 & 0.045 & 0.127 & -0.013 & 0.831 \\
\hline Portugal & 84 & 19 & 199112 & 8.076 & 11 & 5.601 & 0.674 & 0.339 & 1.785 & 6.353 & 0.201 & 22.795 & 0.036 & 0.028 & 0.034 & 0.168 & -0.173 & 1.603 \\
\hline Russia & 29 & 10 & 199612 & 8.914 & 8 & 5.037 & 1.770 & 0.475 & 3.913 & 1.607 & 0.612 & 2.365 & 0.078 & 0.065 & 0.060 & 0.051 & -0.073 & 0.551 \\
\hline South Africa & 116 & 25 & 199012 & 6.740 & 7 & & 0.244 & 0.051 & 0.920 & 0.151 & 0.078 & 0.205 & 0.042 & 0.033 & 0.031 & 0.159 & -0.066 & 1.092 \\
\hline Sri Lanka & 74 & 34 & 199212 & 4.368 & 4 & 2.108 & 0.376 & 0.095 & 0.829 & 0.480 & 0.110 & 2.005 & 0.051 & 0.039 & 0.048 & 0.100 & -0.468 & 1.902 \\
\hline Taiwan & 548 & 82 & 199112 & 7.337 & 6 & 5.460 & 0.423 & 0.134 & 1.004 & 0.607 & 0.204 & 2.249 & 0.043 & 0.036 & 0.032 & 0.178 & -0.284 & 1.259 \\
\hline Thailand & 445 & 81 & 198809 & 13.983 & 13 & 9.108 & 1.644 & 0.120 & 6.644 & 1.092 & 0.187 & 3.841 & 0.056 & 0.044 & 0.041 & 0.302 & -0.261 & 2.421 \\
\hline Turkey & 166 & 32 & 199112 & 13.917 & 14 & 5.896 & 0.799 & 0.124 & 4.433 & 0.504 & 0.248 & 0.807 & 0.079 & 0.068 & 0.049 & 0.351 & -0.072 & 1.259 \\
\hline Venezuela & 10 & 3 & 199412 & 4.800 & 3 & 3.706 & 0.969 & 0.381 & 1.058 & 0.571 & 0.406 & 0.479 & 0.031 & 0.021 & 0.030 & -0.012 & -0.091 & 0.453 \\
\hline Average & 180 & 34 & - & 10.435 & 10 & 6.127 & 1.174 & 0.182 & 7.210 & 1.622 & 0.217 & 5.288 & 0.053 & 0.043 & 0.041 & 0.110 & -0.218 & 1.243 \\
\hline
\end{tabular}




\section{Table 3. Cross-country correlations of annual openness proxies, information measures, and market characteristics.}

This table presents correlations between country annual information environment variables (earnings-related and firm-specific volatility), proxies for openness (investibility and portfolio flow), and market characteristics. The information environment and openness proxies are detailed in Table 2. Each observation represents one year for one country. Because some variables are periodic while earnings-related variables are scattered across the calendar, and information variables are firm specific while openness proxies are country specific, all variables are annualized and summarized across firms to facilitate comparisons as follows. For each country and each year, we compute the median annual information variables (earnings-related and firm-specific volatility) across all firms, the average monthly investibility measure and total portfolio flow, number of firms, and average market capitalization of sample stocks. The average investibility measure and average market capitalization are expressed as natural logs. Total portfolio flow is normalized by the average market capitalization. Firm-specific volatility is transformed into a number not restricted between zero and one with the logistic transformation, log (x)/(1-x)) where $\mathrm{x}$ is the firm-specific volatility detailed in Table 2. P-values and the number of observations are reported below each correlation coefficient. Subsequent empirical results are based on either the firm level information variables (Tables $4,5,6$ ) or the country level data used in this table (Tables 7,8 ). 
Table 3 continued.

\begin{tabular}{|c|c|c|c|c|c|c|c|c|c|c|}
\hline \multicolumn{11}{|c|}{ Panel A: Spearman non-parametric correlation, p-value, and number of observations } \\
\hline & $\begin{array}{c}\text { Number of } \\
\text { analysts }\end{array}$ & $\begin{array}{c}\text { Forecast } \\
\text { error }\end{array}$ & $\begin{array}{c}\text { Forecast } \\
\text { dispersion }\end{array}$ & $\begin{array}{c}\text { Return } \\
\text { volatility }\end{array}$ & $\begin{array}{c}\text { Abnormal } \\
\text { volume }\end{array}$ & $\begin{array}{c}\text { Firm- } \\
\text { specific } \\
\text { volatility }\end{array}$ & $\begin{array}{l}\text { Portfolio } \\
\text { flow }\end{array}$ & $\begin{array}{l}\text { One year } \\
\text { lagged } \\
\text { portfolio } \\
\text { flow }\end{array}$ & $\begin{array}{l}\text { Number of } \\
\text { firms }\end{array}$ & $\begin{array}{c}\text { Market } \\
\text { capitalization }\end{array}$ \\
\hline \multirow[t]{3}{*}{ Forecast error } & -0.1284 & & & & & & & & & \\
\hline & 0.110 & & & & & & & & & \\
\hline & 156 & & & & & & & & & \\
\hline \multirow[t]{3}{*}{ Forecast dispersion } & 0.1773 & 0.5775 & & & & & & & & \\
\hline & 0.027 & $<.001$ & & & & & & & & \\
\hline & 154 & 154 & & & & & & & & \\
\hline \multirow[t]{3}{*}{ Return volatility } & 0.2297 & 0.1966 & 0.2954 & & & & & & & \\
\hline & 0.002 & 0.013 & $<0.001$ & & & & & & & \\
\hline & 175 & 156 & 154 & & & & & & & \\
\hline \multirow[t]{3}{*}{ Abnormal volume } & 0.0380 & 0.1227 & 0.0685 & 0.2797 & & & & & & \\
\hline & 0.617 & 0.127 & 0.398 & $<0.001$ & & & & & & \\
\hline & 175 & 156 & 154 & 175 & & & & & & \\
\hline \multirow[t]{3}{*}{ Firm-specific volatility } & 0.0668 & -0.0343 & -0.0495 & 0.0046 & 0.0155 & & & & & \\
\hline & 0.379 & 0.670 & 0.541 & 0.951 & 0.838 & & & & & \\
\hline & 175 & 156 & 154 & 175 & 175 & & & & & \\
\hline \multirow[t]{3}{*}{ Portfolio flow } & 0.493 & 0.0750 & 0.4198 & 0.1582 & -0.0078 & 0.1354 & & & & \\
\hline & $<.001$ & 0.351 & $<.001$ & 0.036 & 0.917 & 0.073 & & & & \\
\hline & 175 & 156 & 154 & 175 & 175 & 175 & & & & \\
\hline \multirow[t]{3}{*}{ One year lagged portfolio flow } & 0.5110 & 0.0825 & 0.4010 & 0.1976 & 0.0746 & 0.1532 & 0.8045 & & & \\
\hline & $<.001$ & 0.315 & $<.001$ & 0.013 & 0.354 & 0.056 & $<.001$ & & & \\
\hline & 156 & 150 & 148 & 156 & 156 & 156 & 156 & & & \\
\hline \multirow[t]{3}{*}{ Number of firms } & 0.0801 & 0.1934 & 0.1976 & 0.1724 & -0.0447 & 0.0352 & -0.0446 & -0.0950 & & \\
\hline & 0.291 & 0.015 & 0.014 & 0.022 & 0.556 & 0.643 & 0.557 & 0.238 & & \\
\hline & 175 & 156 & 154 & 175 & 175 & 175 & 175 & 156 & & \\
\hline \multirow[t]{3}{*}{ Market capitalization } & 0.2973 & 0.1869 & 0.1934 & 0.1421 & -0.0403 & 0.1098 & 0.0784 & 0.0647 & 0.7502 & \\
\hline & $<.001$ & 0.019 & 0.016 & 0.060 & 0.595 & 0.147 & 0.302 & 0.422 & $<.001$ & \\
\hline & 175 & 156 & 154 & 175 & 175 & 175 & 175 & 156 & 175 & \\
\hline \multirow[t]{3}{*}{ Investibility } & 0.3363 & -0.02412 & 0.1461 & -0.0048 & -0.0196 & -0.0580 & 0.4819 & 0.5151 & -0.3033 & -0.1653 \\
\hline & $<.001$ & 0.768 & 0.074 & 0.950 & 0.799 & 0.452 & $<.001$ & $<.001$ & $<.001$ & 0.031 \\
\hline & 170 & 152 & 150 & 170 & 170 & 170 & 170 & 153 & 170 & 170 \\
\hline
\end{tabular}


Table 3 continued.

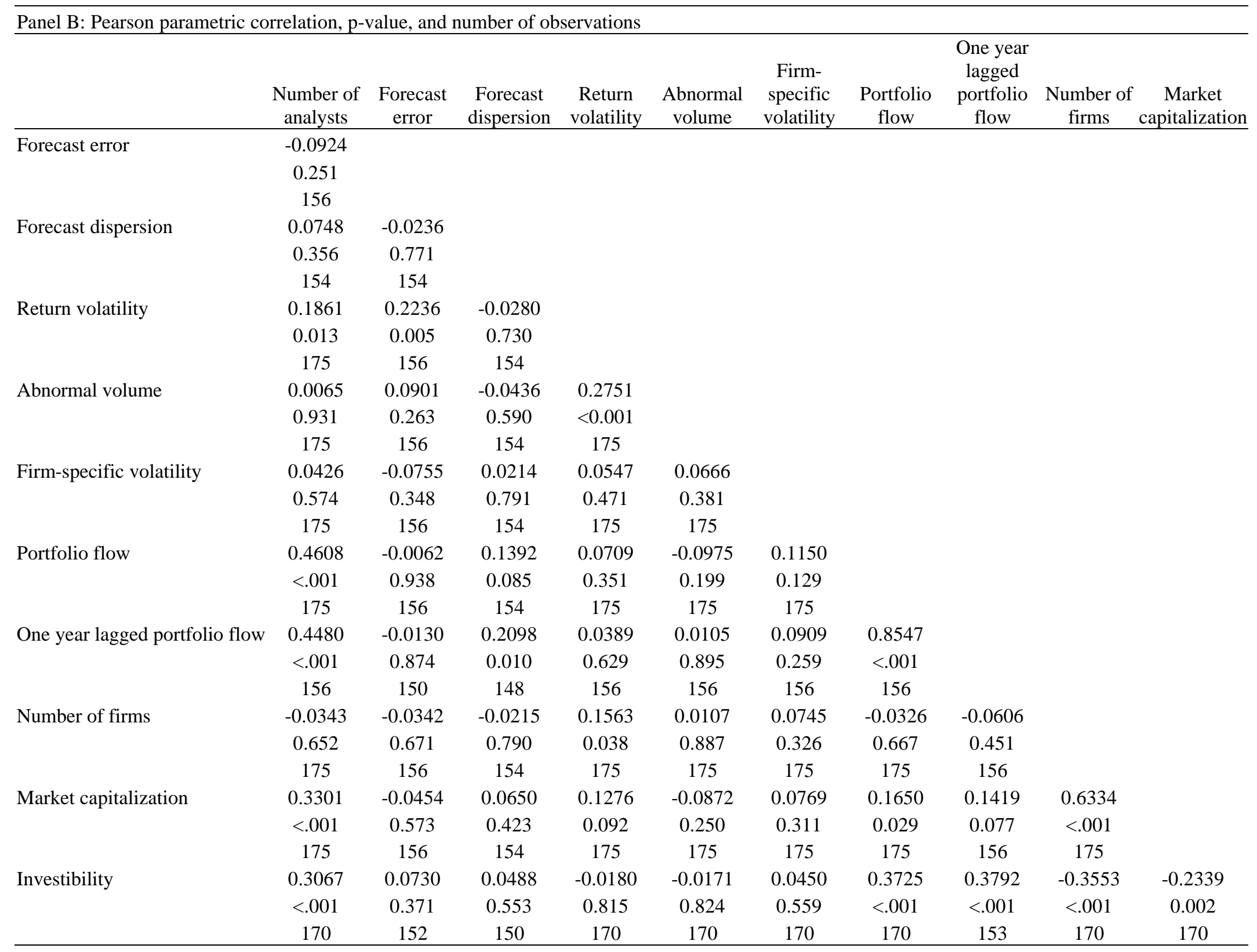




\section{Table 4. Changes in individual firm information variables before versus after various liberalization events}

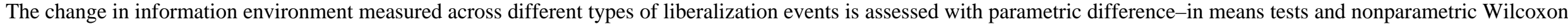

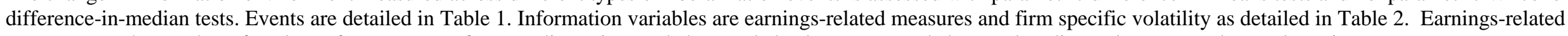

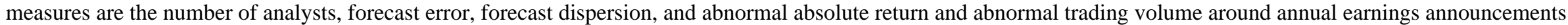

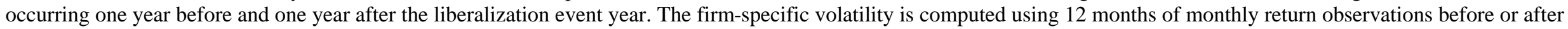

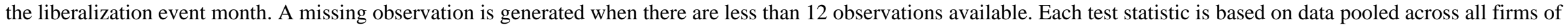

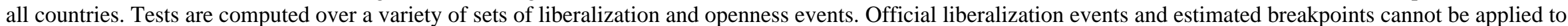

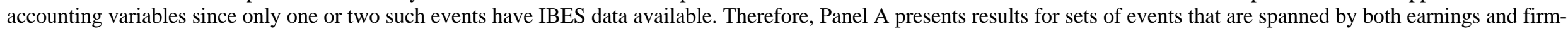

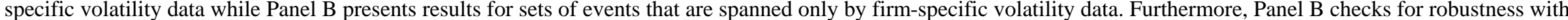

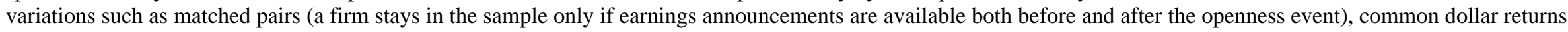

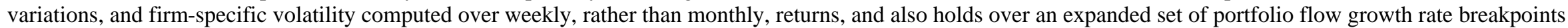


Table 4 continued.

\begin{tabular}{|c|c|c|c|c|c|c|c|c|c|c|c|c|c|c|}
\hline & \multicolumn{3}{|c|}{$\begin{array}{c}\text { Number of } \\
\text { Analysts }\end{array}$} & \multicolumn{2}{|c|}{ Forecast error } & \multicolumn{2}{|c|}{ Forecast dispersion } & \multicolumn{2}{|c|}{$\begin{array}{l}\text { Abnormal absolute } \\
\text { return }\end{array}$} & \multicolumn{2}{|c|}{$\begin{array}{l}\text { Abnormal trading } \\
\text { volume }\end{array}$} & \multicolumn{3}{|c|}{ Firm-specific volatility } \\
\hline & nobs & mean & median & Mean & median & mean & median & mean & median & mean & median & nobs & mean & median \\
\hline \multicolumn{15}{|c|}{$\begin{array}{l}\text { Earliest feasible } \\
\text { liberalization events (V) }\end{array}$} \\
\hline Before & 262 & 6.061 & 4 & 0.423 & 0.081 & 0.279 & 0.127 & 0.054 & 0.039 & 0.310 & -0.142 & 985 & 0.597 & 0.605 \\
\hline After & 295 & 8.634 & 7 & 1.891 & 0.131 & 0.460 & 0.171 & 0.058 & 0.043 & 0.094 & -0.225 & 1029 & 0.618 & 0.648 \\
\hline p-value & & 0.000 & 0.000 & 0.003 & 0.004 & 0.005 & 0.001 & 0.251 & 0.040 & 0.261 & 0.231 & & 0.078 & 0.074 \\
\hline \multicolumn{15}{|c|}{$\begin{array}{l}\text { Earliest feasible } \\
\text { liberalization events, } \\
\text { matched pairs (V) }\end{array}$} \\
\hline After & 195 & 8.344 & 7 & 0.585 & 0.126 & 0.495 & 0.154 & 0.060 & 0.042 & 0.073 & -0.405 & 929 & 0.607 & 0.624 \\
\hline $\mathrm{p}$-value & & 0.013 & 0.013 & 0.019 & 0.016 & 0.007 & 0.001 & 0.016 & 0.025 & 0.906 & 0.511 & & 0.001 & 0.001 \\
\hline \multicolumn{15}{|c|}{$\begin{array}{l}\text { De-liberalization events } \\
\text { (IV) }\end{array}$} \\
\hline Before & 148 & 15.561 & 13 & 1.943 & 0.080 & 0.369 & 0.096 & 0.050 & 0.040 & 0.422 & -0.138 & 257 & 0.542 & 0.519 \\
\hline After & 165 & 13.315 & 10 & 1.166 & 0.154 & 1.110 & 0.192 & 0.061 & 0.045 & 0.067 & -0.354 & 298 & 0.446 & 0.376 \\
\hline p-value & & 0.102 & 0.085 & 0.468 & 0.008 & 0.013 & 0.060 & 0.026 & 0.113 & 0.116 & 0.070 & & 0.000 & 0.000 \\
\hline \multicolumn{15}{|c|}{$\begin{array}{l}\text { ADR or closed end fund } \\
\text { listing events (II) }\end{array}$} \\
\hline Before & 283 & 5.979 & 5 & 0.405 & 0.116 & 0.326 & 0.127 & 0.051 & 0.039 & 0.389 & -0.005 & 1159 & 0.613 & 0.623 \\
\hline p-value & & 0.000 & 0.000 & 0.027 & 0.014 & 0.019 & 0.004 & 0.006 & 0.006 & 0.001 & 0.000 & & 0.000 & 0.000 \\
\hline
\end{tabular}


Table 4 continued.

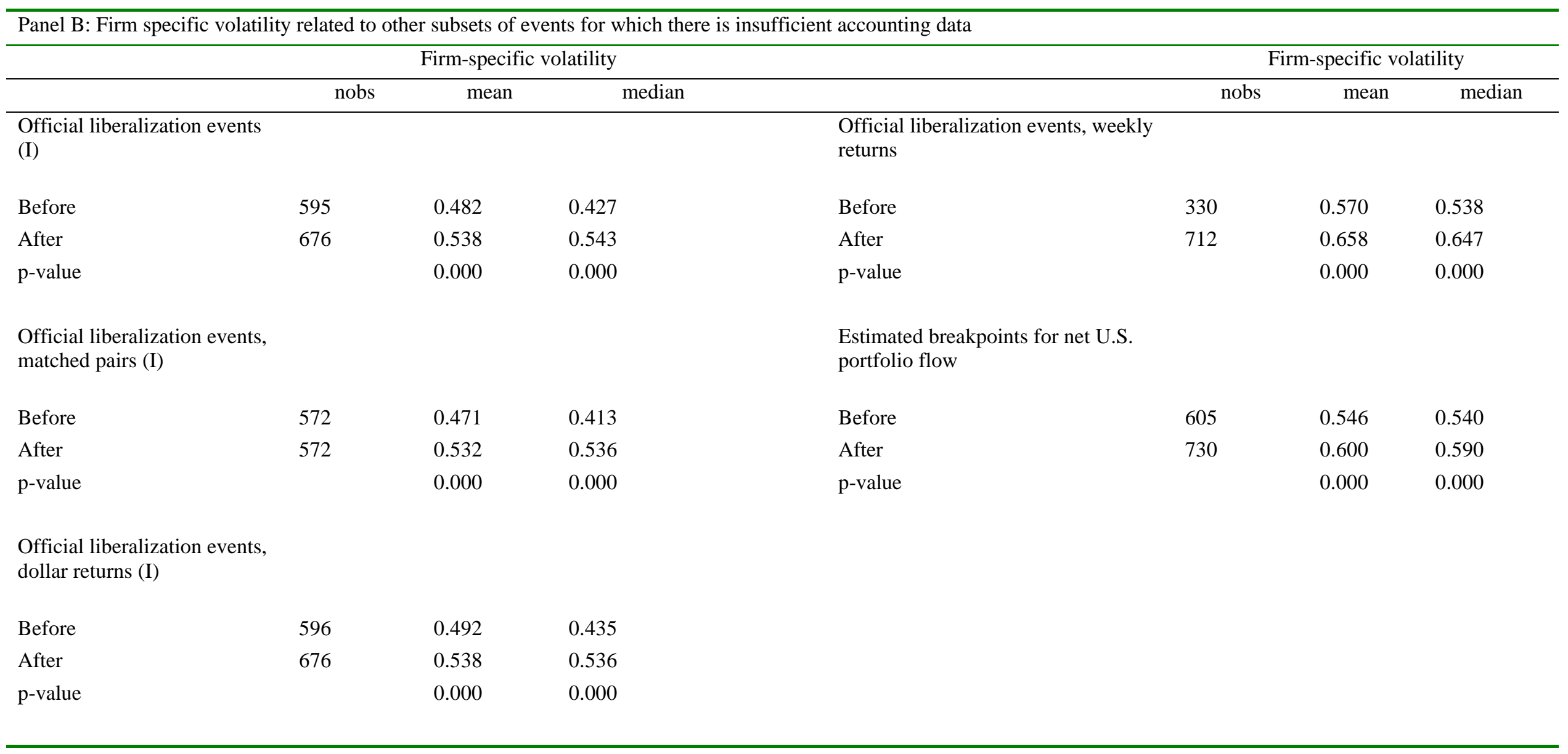


Table 5. Regressions of individual firm information variables on liberalization, cross-listing, and portfolio flow breakpoint, and deliberalization event dummy variables

In Panel A, the dependent variable is the annual firm-specific volatility obtained from a market model run for each firm in each country each year starting from 1986 to 2002. Each regression uses 12 return observations in each year and is not overlapped. Thus, we have cross-sectional time-series firm-specific volatilities as dependent variable. Independent variables are dummy variables that indicate if the time period is one year before and after the liberalization events. In Panel B, the dependent variables are annual individual firm earnings-related measures of the information environment. Independent variables follow those in Panel A. Data limitations yield insufficient observations or imbalanced before versus after numbers of observations for some types of liberalization and openness events. Therefore, this panel uses "earliest feasible events" as in Table 4, Panel B to maintain consistency with that panel. The events are described in Table 1. All regressions control for country and time effects with intercept dummies. Numbers in parentheses are t-statistics and those in brackets are p-values. F-test checks whether the pair of "before" and "after" dummy variables are equal. In specifications with more than one pair of "before" and "after" dummies, F-test checks that the coefficients are equal or jointly equal if there are more than one event included in the regression. 
Table 5 continued.

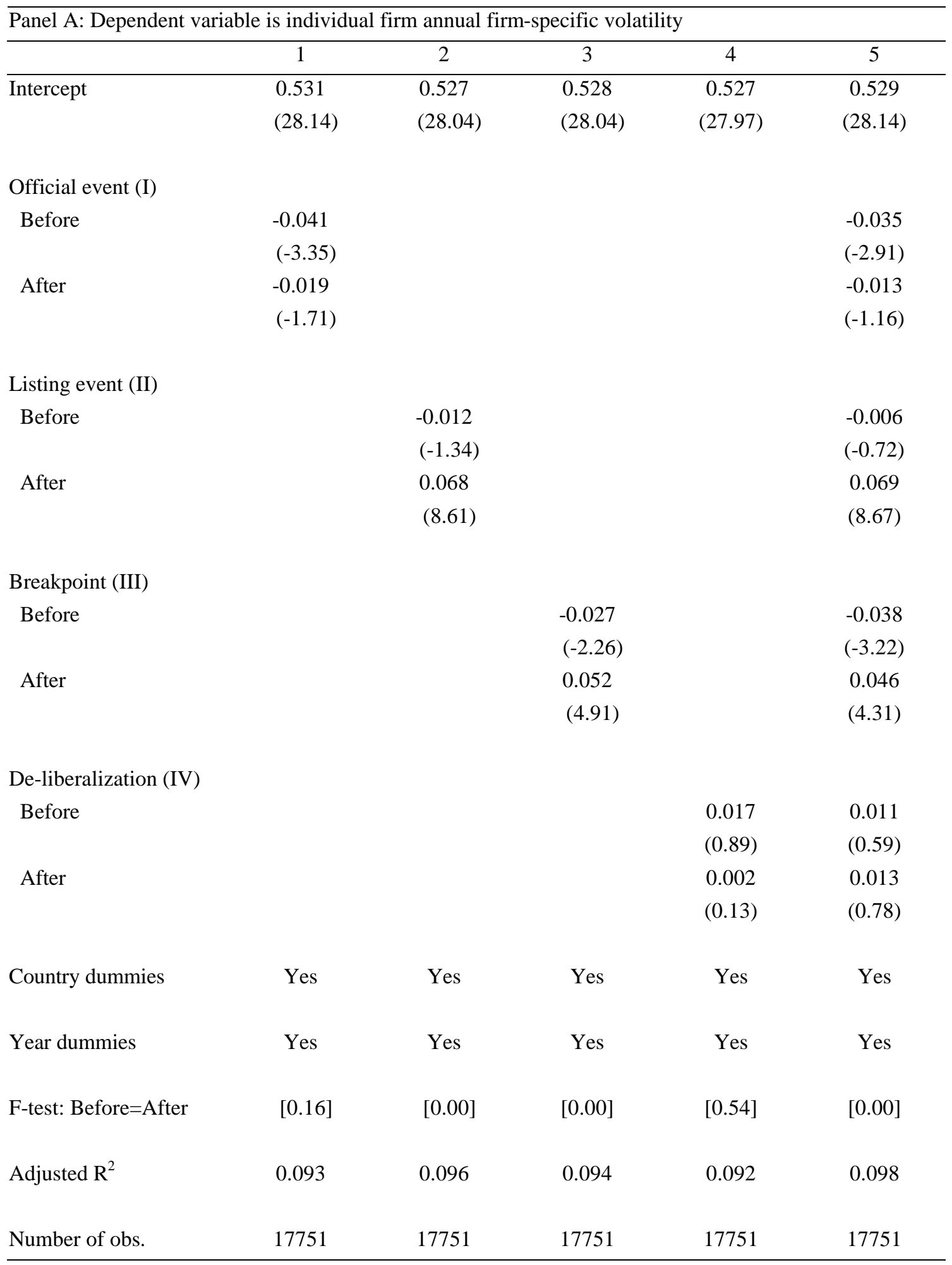




\section{Table 5 continued.}

Panel B: Dependent variables are individual firm earnings-related-based measures of information environment

\begin{tabular}{|c|c|c|c|c|c|c|c|c|c|c|}
\hline & \multicolumn{2}{|c|}{ Number of analysts } & \multicolumn{2}{|c|}{ Absolute forecast error } & \multicolumn{2}{|c|}{ Forecast dispersion } & \multicolumn{2}{|c|}{ Absolute return volatility } & \multicolumn{2}{|c|}{ Abnormal trading volume } \\
\hline & 1 & 2 & 1 & 2 & 1 & 2 & 1 & 2 & 1 & 2 \\
\hline Intercept & 5.9875 & 5.9394 & 1.6255 & 1.9437 & 6.8313 & 6.8853 & 0.0574 & 0.0590 & 0.2933 & 0.3959 \\
\hline & $(1.2759)$ & $(1.2660)$ & $(0.6482)$ & $(0.7470)$ & $(3.8882)$ & $(3.8182)$ & $(16.8373)$ & $(16.7867)$ & $(2.6835)$ & $(3.5167)$ \\
\hline \multicolumn{11}{|c|}{ Earliest feasible events (V) } \\
\hline \multirow[t]{2}{*}{ Before } & 0.5553 & 0.4364 & -2.6271 & -2.7403 & -1.2991 & -1.3552 & -0.0015 & -0.0014 & 0.0599 & 0.0236 \\
\hline & $(0.7696)$ & $(0.5919)$ & $(-1.1714)$ & $(-1.2152)$ & $(-0.8879)$ & $(-0.9206)$ & $(-0.4107)$ & $(-0.2703)$ & $(0.5271)$ & $(0.2068)$ \\
\hline \multirow[t]{2}{*}{ After } & 2.2275 & 2.3276 & 6.0532 & 7.1059 & 3.0846 & 3.3006 & 0.0884 & 0.0719 & 1.3059 & 1.2430 \\
\hline & $(3.4371)$ & $(3.6223)$ & $(2.1031)$ & $(2.0519)$ & $(2.4108)$ & $(2.4924)$ & $(2.2362)$ & $(2.0261)$ & $(2.8804)$ & $(2.4645)$ \\
\hline \multicolumn{11}{|c|}{ De-liberalization (IV) } \\
\hline \multirow[t]{2}{*}{ Before } & & -0.4869 & & 5.6082 & & 3.0299 & & -0.0131 & & -0.9485 \\
\hline & & $(-0.4387)$ & & $(1.1465)$ & & $(0.5852)$ & & $(-1.6796)$ & & $(-3.0146)$ \\
\hline \multirow[t]{2}{*}{ After } & & 2.6474 & & -3.4752 & & -1.4477 & & -0.0109 & & -0.5944 \\
\hline & & $(1.8935)$ & & $(-0.5544)$ & & $(-0.3578)$ & & $(-1.1035)$ & & $(-2.3798)$ \\
\hline Country dummies & Yes & Yes & Yes & Yes & Yes & Yes & Yes & Yes & Yes & Yes \\
\hline Year dummies & Yes & Yes & Yes & Yes & Yes & Yes & Yes & Yes & Yes & Yes \\
\hline F-test: & {$[0.023]$} & {$[0.021]$} & {$[0.033]$} & {$[0.030]$} & {$[0.043]$} & {$[0.038]$} & {$[0.047]$} & {$[0.055]$} & {$[0.137]$} & {$[0.223]$} \\
\hline Adjusted $\mathrm{R}^{2}$ & 0.3098 & 0.3107 & 0.0445 & 0.0451 & 0.0376 & 0.0378 & 0.1102 & 0.1114 & 0.0624 & 0.0672 \\
\hline Number of obs. & 3059 & 3059 & 2549 & 2549 & 2549 & 2549 & 3059 & 3059 & 3059 & 3059 \\
\hline
\end{tabular}


Table 6. Regressions to isolate the "disagreement" component of individual firm trading volume around earnings announcements

The dependent variable is the individual firm-earnings event abnormal trading volume generated as the differences between trading volume and the mean of daily volume for that stock over the pre-announcement window $(-200,-11)$ normalized by the mean volume, then summing over the window of day $(-1,+1)$. Independent variables include dummy variables that take the value if the time period is one year before and after the liberalization events. The number of analysts is the number of analysts following a particular firm. Forecast dispersion is the standard deviation of the most recent individual forecasts scaled by the absolute median forecasts. Abnormal returns are computed based on one-factor market model residuals estimated from day -200 to day -11 at annual earnings announcement with CRSP value-weighted index returns. Abnormal return volatility is the absolute value of daily abnormal returns, summed over the window of day $(-1,+1)$. All regressions control for country and time effects with intercept dummies. T-statistics are reported below each coefficient, and p-values are in brackets. F-test checks that the coefficients on the "before" and "after" dummy of the earliest feasible events are equal.

\begin{tabular}{|c|c|c|c|c|}
\hline & 1 & 2 & 3 & 4 \\
\hline \multirow[t]{2}{*}{ Intercept } & -0.8721 & -0.1921 & -0.7188 & -0.1292 \\
\hline & -2.0122 & -1.4321 & -1.8523 & -0.8324 \\
\hline \multicolumn{5}{|l|}{ Earliest feasible events (V) } \\
\hline \multirow[t]{2}{*}{ Before } & 0.0675 & 0.1762 & 0.0355 & 0.1381 \\
\hline & 0.4709 & 1.1518 & 0.2090 & 0.9431 \\
\hline \multirow[t]{2}{*}{ After } & 0.5432 & 0.5312 & 0.6012 & 0.5133 \\
\hline & 2.5481 & 2.8221 & 2.4324 & 2.7092 \\
\hline \multicolumn{5}{|l|}{ De-liberalization (IV) } \\
\hline \multirow{2}{*}{ Before } & & & -0.0403 & -0.2678 \\
\hline & & & -0.1905 & -0.9885 \\
\hline \multirow[t]{2}{*}{ After } & & & -0.6908 & -0.6433 \\
\hline & & & -1.6535 & -1.8801 \\
\hline \multirow[t]{2}{*}{ Abnormal return volatility } & 8.1799 & 8.7904 & 8.1353 & 8.7345 \\
\hline & 9.2663 & 12.6406 & 9.2112 & 12.5533 \\
\hline \multirow[t]{2}{*}{ Market capitalization } & 0.0391 & & 0.0387 & \\
\hline & 1.1705 & & 1.1588 & \\
\hline \multirow[t]{2}{*}{ Number of analysts } & & -0.0044 & & -0.0034 \\
\hline & & -0.6276 & & -0.4633 \\
\hline \multirow[t]{2}{*}{ Forecast dispersion } & -0.0004 & -0.0001 & -0.0004 & -0.0001 \\
\hline & -1.7040 & -0.4715 & -1.8948 & -0.6422 \\
\hline Country dummies & Yes & Yes & Yes & Yes \\
\hline Year dummies & Yes & Yes & Yes & Yes \\
\hline F-test: & [0.087] & [0.103] & [0.112] & [0.156] \\
\hline Adjusted $\mathrm{R}^{2}$ & 0.093 & 0.101 & 0.095 & 0.099 \\
\hline
\end{tabular}


Table 7. Regressions of country average firm-specific volatility on investibility and portfolio flows

The dependent variable is the average firm-specific volatility by year and country. First, the firm- specific volatility is obtained from a market model run for each firm in each country each year starting from 1988 to 2002. Each regression uses 12 return observations in each year and is not overlapped. Then, for each year in each country, the median is obtained from firm-specific volatilities across sample firms within each country. Thus, we have crosssectional time-series median firm-specific volatilities as dependent variable. Independent variables are 1) one-year average of investibility measure, 2) number of firms included in computing median volatility, 3) average firm market capitalization, 4) country dummies, and 5) year dummies. Average investibility measure and average market capitalization are expressed in natural logs. Total portfolio flow is normalized by the average market capitalization. Firm-specific volatility is transformed into a number not restricted between zero and one with the logistic transformation $\log (\mathrm{x}) /(1-\mathrm{x}))$ where $\mathrm{x}$ is the firm-specific volatility. Models (1) through (3) use investibility and models (4) through (6) use portfolio flow.

\begin{tabular}{|c|c|c|c|c|c|c|}
\hline & 1 & 2 & 3 & 4 & 5 & 6 \\
\hline \multirow[t]{2}{*}{ Intercept } & -1.609 & -1.515 & -1.862 & -1.176 & -1.213 & -1.295 \\
\hline & $(-2.09)$ & $(-1.77)$ & $(-2.22)$ & $(-1.50)$ & $(-1.45)$ & $(-1.50)$ \\
\hline \multirow[t]{2}{*}{ Investibility } & -0.361 & & -0.432 & & & \\
\hline & $(-1.20)$ & & $(-0.89)$ & & & \\
\hline \multirow[t]{2}{*}{ Lagged investibility } & & -0.321 & 0.169 & & & \\
\hline & & $(-1.00)$ & $(0.35)$ & & & \\
\hline \multirow[t]{2}{*}{ Portfolio flow } & & & & 5.706 & & 1.863 \\
\hline & & & & (1.33) & & $(0.42)$ \\
\hline \multirow[t]{2}{*}{ Lagged portfolio flow } & & & & & 10.145 & 9.286 \\
\hline & & & & & $(2.04)$ & $(1.71)$ \\
\hline \multirow[t]{2}{*}{ Number of firms } & 0.007 & 0.004 & 0.004 & 0.010 & 0.013 & 0.013 \\
\hline & $(1.75)$ & $(1.03)$ & (1.06) & (3.82) & $(4.20)$ & $(4.22)$ \\
\hline \multirow[t]{2}{*}{ Market capitalization } & 0.168 & 0.159 & 0.197 & 0.110 & 0.095 & 0.102 \\
\hline & $(1.84)$ & (1.61) & $(2.04)$ & (1.19) & $(0.99)$ & (1.04) \\
\hline Country dummies & Yes & Yes & Yes & Yes & Yes & Yes \\
\hline Year dummies & Yes & Yes & Yes & Yes & Yes & Yes \\
\hline Adjusted $\mathrm{R}^{2}$ & 0.247 & 0.257 & 0.279 & 0.226 & 0.264 & 0.261 \\
\hline Number of observations & 304 & 282 & 282 & 317 & 292 & 292 \\
\hline
\end{tabular}




\section{Table 8. Regression of country median earnings-related measures on investibility and portfolio flows}

The dependent variables are the median annual earnings-related measures across all firms by country as defined in Table 2. Each observation represents one year for one country. Independent variables are the investibility measure (Panel A) or total portfolio flow (Panel B), number of firms, average market capitalization of stocks, country dummies, and year dummies. For each country each year, we compute the median annual information variables (earnings-related-based and firm-specific volatility) across all firms, the average monthly investibility measure and total portfolio flow, number of firms, and average market capitalization of sample firms. The average investibility measure and average market capitalization are expressed as natural logs. Total portfolio flow is the average total portfolio flow during the year, that is, the mean of 12 monthly total flows, divided by the average market capitalization during the year. T-statistics are reported below each coefficient.

\begin{tabular}{|c|c|c|c|c|c|c|c|c|c|c|c|c|}
\hline \multicolumn{13}{|c|}{ Panel A. Investibility proxy for openness } \\
\hline & \multicolumn{4}{|c|}{ Number of analysts } & \multicolumn{5}{|c|}{ Absolute forecast error } & \multicolumn{2}{|c|}{ Forecast dispersion } & \multirow[b]{2}{*}{4} \\
\hline & 1 & 2 & 3 & 4 & 1 & 2 & 3 & 4 & 1 & 2 & 3 & \\
\hline \multirow[t]{2}{*}{ Intercept } & 1.8389 & -18.7566 & -16.7267 & -16.7996 & -0.1260 & 0.6949 & 0.6781 & 0.5571 & -0.1590 & 0.6354 & 0.5982 & 0.4687 \\
\hline & 0.7448 & -3.1030 & -2.5544 & -2.5416 & -0.9316 & 1.4933 & 1.3303 & 1.1106 & -1.3686 & 1.5327 & 1.3274 & 1.0662 \\
\hline \multirow[t]{2}{*}{ Investibility } & -1.7352 & -1.1309 & & 0.2038 & 0.2904 & 0.2846 & & 0.3441 & 0.3666 & 0.3606 & & 0.3392 \\
\hline & -1.5840 & -1.0716 & & 0.1164 & 3.7091 & 3.6684 & & 2.4275 & 5.3975 & 5.3692 & & 2.8297 \\
\hline \multirow[t]{2}{*}{ Investibility lagged } & & & -0.9779 & -1.1418 & & & 0.1841 & -0.0940 & & & 0.2632 & -0.0090 \\
\hline & & & -0.8952 & -0.6395 & & & 2.2529 & -0.6724 & & & 3.7327 & -0.0763 \\
\hline \multirow[t]{2}{*}{ Number of firms } & -0.0631 & -0.0685 & -0.0517 & -0.0523 & -0.0011 & -0.0004 & 0.0003 & -0.0006 & -0.0014 & -0.0005 & 0.0003 & -0.0007 \\
\hline & -2.8696 & -3.2693 & -2.2568 & -2.2198 & -0.7790 & -0.2343 & 0.2006 & -0.3483 & -1.0655 & -0.3942 & 0.2040 & -0.4451 \\
\hline \multirow[t]{2}{*}{ Market capitalization } & & 2.4929 & 2.2416 & 2.2511 & & -0.0920 & -0.0928 & -0.0792 & & -0.0892 & -0.0896 & -0.0750 \\
\hline & & 3.6981 & 3.2602 & 3.2357 & & -1.8419 & -1.7456 & -1.5121 & & -1.9943 & -1.8930 & -1.6233 \\
\hline Country dummies & Yes & Yes & Yes & Yes & Yes & Yes & Yes & Yes & Yes & Yes & Yes & Yes \\
\hline Year dummies & Yes & Yes & Yes & Yes & Yes & Yes & Yes & Yes & Yes & Yes & Yes & Yes \\
\hline Adjusted $\mathrm{R}^{2}$ & 0.7454 & 0.7713 & 0.7904 & 0.7904 & 0.6540 & 0.6635 & 0.6515 & 0.6687 & 0.7402 & 0.7487 & 0.7443 & 0.7615 \\
\hline Nobs & 160 & 160 & 160 & 160 & 142 & 142 & 142 & 142 & 142 & 142 & 142 & 142 \\
\hline
\end{tabular}

Table 8 continued next page. 
Table 8 continued.

\begin{tabular}{|c|c|c|c|c|c|c|c|c|}
\hline \multicolumn{9}{|l|}{ Panel A continued. } \\
\hline & \multicolumn{5}{|c|}{ Abnormal return volatility } & \multicolumn{3}{|c|}{ Abnormal trading volume } \\
\hline & 1 & 2 & 3 & 4 & 1 & 2 & 3 & 4 \\
\hline \multirow[t]{2}{*}{ Intercept } & 0.0570 & 0.0581 & 0.0971 & 0.0950 & 0.1322 & 0.7611 & 1.1082 & 1.0796 \\
\hline & 5.8070 & 2.4635 & 3.5720 & 3.4753 & 0.5567 & 1.3418 & 1.6528 & 1.5973 \\
\hline \multirow[t]{2}{*}{ Investibility } & 0.0057 & 0.0057 & & 0.0062 & 0.0491 & 0.0128 & & 0.0851 \\
\hline & 1.9986 & 1.8072 & & 0.8342 & 0.7106 & 0.1704 & & 0.4616 \\
\hline \multirow[t]{2}{*}{ Investibility lagged } & & & 0.0068 & 0.0013 & & & 0.0525 & -0.0221 \\
\hline & & & 1.9957 & 0.1783 & & & 0.6279 & -0.1213 \\
\hline \multirow[t]{2}{*}{ Number of firms } & -0.0001 & -0.0001 & -0.0001 & -0.0001 & 0.0009 & 0.0012 & 0.0012 & 0.0010 \\
\hline & -1.1739 & -1.1582 & -0.7087 & -0.8505 & 0.4570 & 0.5772 & 0.5042 & 0.4077 \\
\hline \multirow[t]{2}{*}{ Market capitalization } & & -0.0001 & -0.0039 & -0.0036 & & -0.0775 & -0.1363 & -0.1324 \\
\hline & & -0.0517 & -1.3582 & -1.2454 & & -1.2203 & -1.9417 & -1.8644 \\
\hline Country dummies & Yes & Yes & Yes & Yes & Yes & Yes & Yes & Yes \\
\hline Year dummies & Yes & Yes & Yes & Yes & Yes & Yes & Yes & Yes \\
\hline Adjusted $\mathrm{R}^{2}$ & 0.4100 & 0.4100 & 0.4583 & 0.4619 & 0.1685 & 0.1784 & 0.2216 & 0.2232 \\
\hline Nobs & 160 & 160 & 160 & 160 & 142 & 142 & 142 & 142 \\
\hline
\end{tabular}

Table 8 continued next page. 


\section{Table 8 continued.}

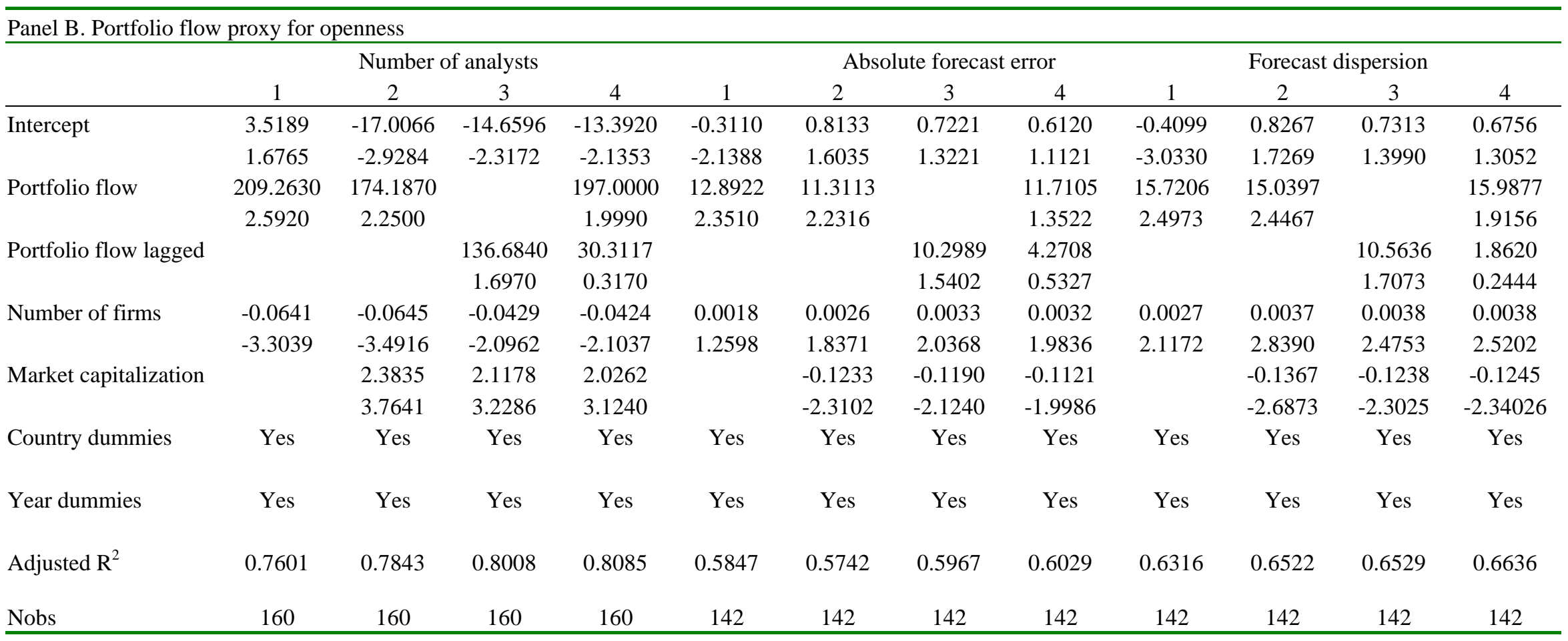

Table 8 continued next page. 


\section{Table 8 continued.}

\begin{tabular}{|c|c|c|c|c|c|c|c|c|}
\hline \multicolumn{9}{|l|}{ Panel B continued. } \\
\hline & \multicolumn{5}{|c|}{ Abnormal return volatility } & \multicolumn{3}{|c|}{ Abnormal trading volume } \\
\hline & 1 & 2 & 3 & 4 & 1 & 2 & 3 & 4 \\
\hline \multirow[t]{2}{*}{ Intercept } & 0.0457 & 0.0758 & 0.1038 & 0.1032 & 0.0576 & 0.6840 & 0.9187 & 1.0422 \\
\hline & 5.5061 & 3.3927 & 3.9398 & 3.8819 & 0.2963 & 1.3039 & 1.4550 & 1.6697 \\
\hline \multirow[t]{2}{*}{ Portfolio flow } & -0.1165 & -0.1748 & & 0.1159 & -10.8967 & -12.1059 & & -22.5169 \\
\hline & -0.3468 & -0.5187 & & 0.2571 & -1.3843 & -1.5308 & & -1.8254 \\
\hline \multirow[t]{2}{*}{ Portfolio flow lagged } & & & -0.0287 & -0.0933 & & & 4.8907 & 17.4425 \\
\hline & & & -0.0788 & -0.2103 & & & 0.5604 & 1.6734 \\
\hline \multirow[t]{2}{*}{ Number of firms } & -0.0001 & -0.0001 & 0.0000 & 0.0000 & 0.0018 & 0.0022 & 0.0013 & 0.0012 \\
\hline & -1.0228 & -0.7683 & -0.4115 & -0.4026 & 0.9916 & 1.1959 & 0.6340 & 0.5852 \\
\hline \multirow[t]{2}{*}{ Market capitalization } & & -0.0034 & -0.0057 & -0.0057 & & -0.0699 & -0.1159 & -0.1260 \\
\hline & & -1.4530 & -2.1979 & -2.1623 & & -1.2850 & -1.8412 & -2.0285 \\
\hline Country dummies & Yes & Yes & Yes & Yes & Yes & Yes & Yes & Yes \\
\hline Year dummies & Yes & Yes & Yes & Yes & Yes & Yes & Yes & Yes \\
\hline $\mathrm{R}^{2}$ & 0.3729 & 0.3831 & 0.4184 & 0.4188 & 0.1811 & 0.1915 & 0.2169 & 0.2483 \\
\hline Nobs & 142 & 142 & 142 & 142 & 142 & 142 & 142 & 142 \\
\hline
\end{tabular}


Table 9. Regressions of individual Korean firm-specific volatility on investibility, portfolio flow, and firm characteristics

From all Korean firms listed during 1987 to 2001, we select non-financial firms with fiscal year ending in December, yielding about 400 to 500 firms yearly. For each firm-year, we compute firm-specific volatility from a market model run for each year from 1988 to 2002. Each regression uses 12 return observations in each year and is not overlapped. Firm-specific volatility is transformed into a number not restricted between zero and one with the logistic transformation $\log (\mathrm{x}) /(1-\mathrm{x}))$ where $\mathrm{x}$ is the firm-specific volatility. Independent firm-specific variables log of market cap, cash flow (operating income plus depreciation divided by total assets), fraction of total assets invested in affiliated firms, a dummy variable for membership in a chaebol, and the fraction of total equity held by foreign investors. Independent aggregate variables are yearly average of the investibility and portfolio flow measures for each country. T-statistics are reported in parentheses to the right of each coefficient estimate.

\begin{tabular}{|c|c|c|c|c|c|c|c|c|}
\hline & 1 & & 2 & & 3 & & 4 & \\
\hline Intercept & 2.6282 & (13.12) & 2.4068 & (11.62) & 2.8494 & (15.30) & 2.8331 & (15.03) \\
\hline Investibility & 0.0131 & $(1.43)$ & & & & & & \\
\hline Lagged investibility & & & 0.1432 & (12.85) & & & & \\
\hline Portfolio flow & & & & & 3.6729 & $(5.66)$ & & \\
\hline Lagged Portfolio flow & & & & & & & 4.5705 & $(6.23)$ \\
\hline Market capitalization & -0.5874 & $(-9.29)$ & -0.5302 & $(-8.10)$ & -0.6696 & $(-11.38)$ & -0.6632 & $(-11.14)$ \\
\hline Cash flow / Total assets & 0.0136 & $(1.14)$ & 0.0175 & $(1.44)$ & 0.0050 & $(0.42)$ & 0.0073 & $(0.60)$ \\
\hline $\begin{array}{l}\text { Invest in affiliates / Total } \\
\text { assets }\end{array}$ & -0.0737 & $(-5.86)$ & -0.0837 & $(-6.41)$ & -0.0681 & $(-5.75)$ & -0.0721 & $(-6.01)$ \\
\hline Chaebol dummy & -0.0517 & $(-6.26)$ & -0.0446 & $(-5.11)$ & -0.0548 & $(-7.36)$ & -0.0570 & $(-7.51)$ \\
\hline $\begin{array}{l}\text { Fraction of foreign } \\
\text { ownership }\end{array}$ & $-6.8 \mathrm{E}-05$ & $(-0.20)$ & -0.0004 & $(-1.14)$ & 0.0007 & $(2.34)$ & 0.0007 & $(2.23)$ \\
\hline Adjusted $\mathrm{R}^{2}$ & 0.066 & & 0.098 & & 0.074 & & 0.077 & \\
\hline Number of observations & 4389 & & 3932 & & 5785 & & 5546 & \\
\hline
\end{tabular}


Table 10. Regression of individual Korean firm earnings-related measures on investibility, portfolio flow, and firm characteristics 


\section{Table 11. Lead-lag associations between information and openness measures}

This table summarizes the results of a VAR that relates information and openness measures to their own lags:

information variable $(\mathrm{t})=\mathrm{a}_{1}+\sum_{\mathrm{t}=1, \mathrm{j}}\left[\mathrm{b}_{1 \mathrm{j}}\right.$ information variable $(\mathrm{t}-\mathrm{j})+\mathrm{c}_{1 \mathrm{j}}$ openness measure $\left.(\mathrm{t}-\mathrm{j})\right]+$ error $(1, \mathrm{t})$

openness measure $(t) \quad=a_{2}+\sum_{t=1, j}\left[b_{2 j}\right.$ information variable $(t-j)+c_{2 j}$ openness measure $\left.(t-j)\right]+$ error $(2, t)$

The information variable is the average firm-specific volatility by year and country or one of the median annual earnings-related measures across all firms by country as defined in Table 2. The openness measure is the average monthly investibility or the total U.S. portfolio flow. All variables are annual country averages pooled across all countries and years. The table reports p-values from Wald tests of the null hypothesis that a set of coefficients are jointly equal.

\begin{tabular}{|c|c|c|c|c|c|c|c|c|}
\hline \multirow[b]{2}{*}{ Information variable } & \multirow[b]{2}{*}{ Openness measure } & \multirow[b]{2}{*}{$\begin{array}{l}\text { Number of } \\
\text { observations }\end{array}$} & \multicolumn{3}{|c|}{$\begin{array}{l}\text { Openness leads information: } \\
\text { P-value testing } \mathrm{c}_{1 \mathrm{j}} \text { jointly zero }\end{array}$} & \multicolumn{3}{|c|}{$\begin{array}{l}\text { Information leads openness: } \\
\text { P-value testing } \mathrm{b}_{2 \mathrm{j}} \text { jointly zero }\end{array}$} \\
\hline & & & $1 \mathrm{lag}$ & 2 lags & 3 lags & $1 \mathrm{lag}$ & 2 lags & 3 lags \\
\hline Firm-specific volatility & Total U.S. portfolio flow & 327 & 0.0964 & 0.0519 & 0.0578 & 0.6510 & 0.3983 & 0.5019 \\
\hline Number of Analysts & Total U.S. portfolio flow & 137 & 0.0308 & 0.0638 & 0.0571 & 0.0001 & 0.0001 & 0.0111 \\
\hline Forecast error & Total U.S. portfolio flow & 137 & 0.8370 & 0.7735 & 0.8630 & 0.7226 & 0.8836 & 0.9729 \\
\hline Forecast dispersion & Total U.S. portfolio flow & 137 & 0.4284 & 0.7235 & 0.8612 & 0.6329 & 0.6366 & 0.8153 \\
\hline Abnormal absolute return & Total U.S. portfolio flow & 137 & 0.8461 & 0.4641 & 0.9764 & 0.4926 & 0.3058 & 0.5199 \\
\hline Abnormal trading volume & Total U.S. portfolio flow & 137 & 0.9451 & 0.5767 & 0.8597 & 0.2231 & 0.8456 & 0.2738 \\
\hline Firm-specific volatility & Investibility & 327 & 0.9151 & 0.0256 & 0.1235 & 0.7670 & 0.8616 & 0.5759 \\
\hline Number of Analysts & Investibility & 137 & 0.1615 & 0.2704 & 0.2459 & 0.2435 & 0.7606 & 0.6615 \\
\hline Forecast error & Investibility & 137 & 0.0108 & 0.0423 & 0.0073 & 0.1575 & 0.2267 & 0.0140 \\
\hline Forecast dispersion & Investibility & 137 & 0.0282 & 0.0186 & 0.0423 & 0.0768 & 0.0855 & 0.0733 \\
\hline Abnormal absolute return & Investibility & 137 & 0.9563 & 0.8738 & 0.3090 & 0.1467 & 0.2006 & 0.1822 \\
\hline Abnormal trading volume & Investibility & 137 & 0.6604 & 0.7088 & 0.8796 & 0.7742 & 0.3332 & 0.4749 \\
\hline
\end{tabular}




\section{Appendix 1. Official liberalization events, overseas listings, and country fund listings}

"Early official liberalization" events are outlined on pages 608 to 611 of Bekaert and Harvey (2000). "Additional official liberalization" events are more recent events gathered from a variety of sources. Overseas listings and listed country funds date sources include web pages of Bank of New York, London Stock Exchange, The Internet Closed End Fund Investor, and Campbell Harvey, and papers authored by Bekaert and Harvey (1996), Patro (2002), and Bekaert, Harvey, and Lundblad (2003). "DELIB" indicates that the event raised, rather than lowered, foreign access to the local stock market. "EMDB", "IBES", or "DS" indicate whether data spans the event. Market data spans the event if there are at least a handful of firms with data going back at least one year before the event. Earnings data spans the event if there is at least one earnings announcement before the event. We exclude 1950s and 1960s events for Malaysia and Mexico, and apartheid-era events for South Africa.

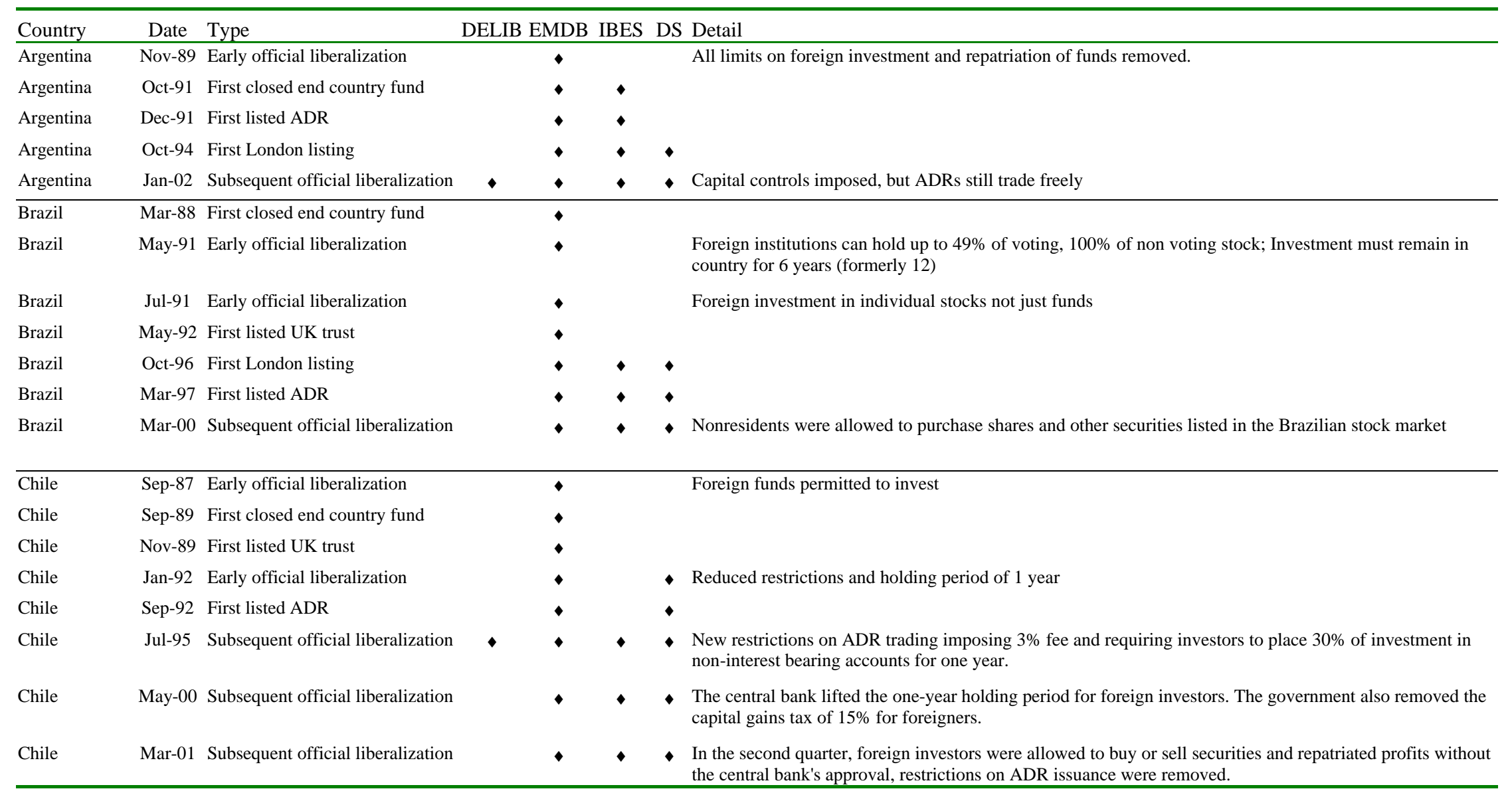




\begin{tabular}{|c|c|c|c|c|c|}
\hline Chile & Dec-02 & First London listing & - & 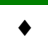 & - \\
\hline$\overline{\text { China }}$ & Jul-92 & First closed end country fund & & & \\
\hline China & Jul-93 & First listed ADR & & & - \\
\hline China & Oct-93 & First listed UK trust & & & - \\
\hline China & Mar-97 & First London listing & $\bullet$ & • & - \\
\hline China & Mar-03 & Subsequent official liberalization & $\bullet$ & $\bullet$ & B-share market opened to domestic investors. \\
\hline Colombia & Feb-91 & Early official liberalization & $\bullet$ & & All legal limits on foreign investment and repatriation of funds removed \\
\hline Colombia & Jan-92 & Subsequent official liberalization & $\bullet$ & & Colombian residents allowed to hold foreign stocks and other portfolio investments abroad. \\
\hline Colombia & Jul-95 & First listed ADR & • & - & - \\
\hline Czech Rep & Aug-92 & First listed UK trust & & & \\
\hline Czech Rep & Sep-94 & First closed end country fund & & & \\
\hline Czech Rep & Jul-95 & First London listing & $\bullet$ & & - \\
\hline Egypt & Jun-92 & Subsequent official liberalization & & & The Capital Market Law 95 grants foreign investors full access to capital markets \\
\hline Egypt & Jul-96 & First London listing & & & \\
\hline Egypt & Aug-96 & First listed UK trust & & & \\
\hline Egypt & May-97 & Subsequent official liberalization & $\bullet$ & & $\begin{array}{l}\text { Investment Incentives and Guarantees Law } 8 \text { of } 1997 \text { allows } 100 \% \text { foreign ownership, guarantees right to } \\
\text { remit income and repatriate capital and profits, and equal treatment regardless of nationality. }\end{array}$ \\
\hline Greece & Dec-87 & Early official liberalization & - & & Europeans allowed to invest, repatriate \\
\hline Greece & Sep-88 & First listed UK trust & • & & \\
\hline Greece & Dec- 88 & Early official liberalization & • & & Non Europeans allowed to invest, repatriate \\
\hline Greece & Jun-97 & First London listing & $\bullet$ & - & - \\
\hline Greece & Oct-98 & First listed ADR & $\bullet$ & • & $\bullet$ \\
\hline Hungary & Jan-96 & Subsequent official liberalization & $\bullet$ & 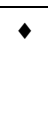 & $\begin{array}{l}\text { Some capital account restrictions eliminated; foreigners allowed to buy most Hungarian securities with } \\
\text { maturities longer than one year without permission, and outward equity investment was permitted, provided } \\
\text { that an equity share of over } 10 \% \text { is acquired }\end{array}$ \\
\hline Hungary & Mar-96 & First London listing & • & - & $\bullet$ \\
\hline Hungary & Nov-97 & First listed ADR & $\bullet$ & $\bullet$ & $\bullet$ \\
\hline India & Jun-76 & First London listing & & & \\
\hline India & Aug-86 & First listed UK trust & • & & \\
\hline India & Aug- 88 & First closed end country fund & • & & \\
\hline India & Nov-92 & Early official liberalization & • & & Foreigners permitted to invest in equities \\
\hline India & Mar-99 & First listed ADR & • & • & - \\
\hline India & Apr-01 & Subsequent official liberalization & $\bullet$ & - & - The government opened equity markets further, removing foreign ownership ceilings in many sectors. \\
\hline Indonesia & Sep-89 & Early official liberalization & & & Foreigners can buy up to $49 \%$ of non financial firms \\
\hline Indonesia & Mar-90 & First closed end country fund & & & \\
\hline Indonesia & May-90 & First listed UK trust & & & \\
\hline
\end{tabular}




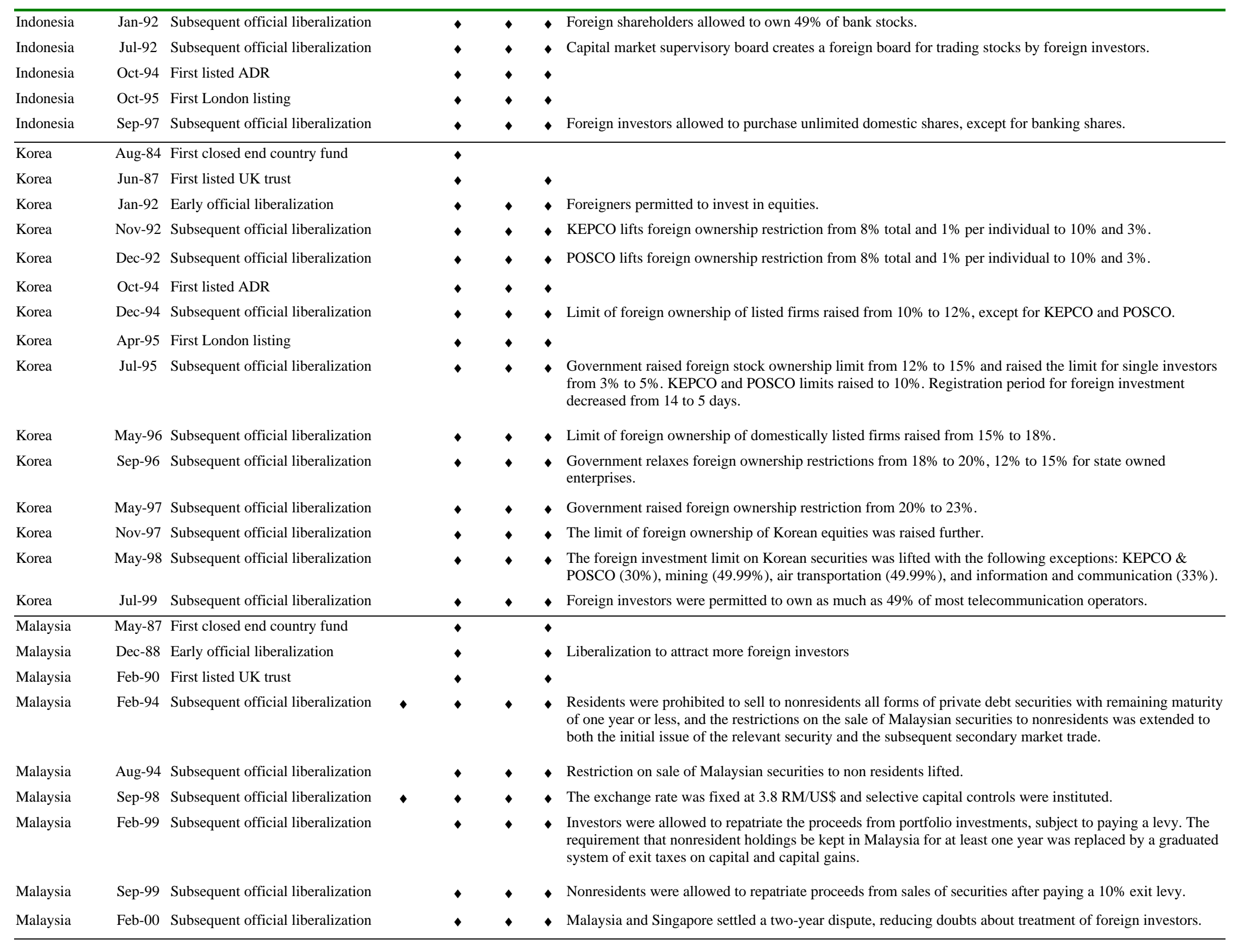




\begin{tabular}{|c|c|c|c|c|c|c|}
\hline Mexico & Jun-81 & First closed end country fund & & $\bullet$ & & \\
\hline Mexico & Jan-89 & First listed ADR (modern era) & & & & \\
\hline Mexico & May-89 & Early official liberalization & & • & & - Relaxation of foreign investment restrictions \\
\hline Mexico & Nov-89 & Subsequent official liberalization & & $\bullet$ & & - Nafinsa Trust established, allowing foreign investors to hold voting shares. \\
\hline Morocco & Dec-89 & Subsequent official liberalization & & & & Limit of $49 \%$ on foreign participation in local enterprises was lifted, for most sectors. \\
\hline Morocco & Apr-96 & First London listing & & & & • \\
\hline Pakistan & Feb-91 & Early official liberalization & & $\bullet$ & & Partial liberalization of foreign access to equities \\
\hline Pakistan & Dec-93 & First closed end country fund & & - & & - \\
\hline Peru & Oct-92 & Subsequent official liberalization & & & & Supreme Decree 162 effects Legislative Decree 662 (29 Aug 1991) opening fully to foreign stock investors. \\
\hline Peru & May-96 & First listed ADR & & $\bullet$ & $\bullet$ & • \\
\hline Philippines & Nov-89 & First closed end country fund & & - & & \\
\hline Philippines & Dec-89 & First listed UK trust & & - & & \\
\hline Philippines & Jun-91 & Early official liberalization & & • & $\bullet$ & - Gradual removal of foreign ownership restrictions is enacted \\
\hline Philippines & Dec-93 & Subsequent official liberalization & & - & $\bullet$ & - By end of 1993 residents can freely own foreign securities \\
\hline Philippines & Mar-00 & First listed ADR & & $\bullet$ & $\bullet$ & - \\
\hline Poland & Jul-97 & First London listing & & $\cdot$ & $\bullet$ & $\bullet$ \\
\hline Poland & Jul-99 & First listed ADR & & - & $\bullet$ & $\bullet$ \\
\hline Portugal & Jul-86 & Early official liberalization & & & & Eliminates almost all restrictions on foreign ownership of equities \\
\hline Portugal & Aug-87 & First listed UK trust & & • & & \\
\hline Portugal & Nov-89 & First closed end country fund & & $\bullet$ & & \\
\hline Portugal & Jun-95 & First listed ADR & & • & $\bullet$ & $\bullet$ \\
\hline Portugal & Oct-96 & First London listing & & $\bullet$ & $\bullet$ & $\bullet$ \\
\hline Russia & Jul-91 & Subsequent official liberalization & & & & The 1991 investment code guaranteed foreign investors rights equal to those enjoyed by Russian investors. \\
\hline Russia & Jun-95 & First closed end country fund & & & & \\
\hline Russia & Oct-96 & First London listing & & & & • \\
\hline Russia & Nov-96 & First listed ADR & & • & & - \\
\hline Russia & May-97 & Subsequent official liberalization & $\bullet$ & • & & - Presidential decree limited foreign ownership to $9 \%$ of Gazprom capital, and only through its ADRs. \\
\hline South Africa & Jun-92 & First London listing (modern era) & & & $\bullet$ & $\bullet$ \\
\hline South Africa & Mar-94 & First closed end country fund & & $\bullet$ & - & • \\
\hline South Africa & Jun-94 & First listed ADR & & - & $\bullet$ & $\bullet$ \\
\hline South Africa & Jul-94 & First listed UK trust & & - & $\bullet$ & - \\
\hline Sri Lanka & Jan-00 & Subsequent official liberalization & & • & $\bullet$ & $\begin{array}{l}\text { Limits on foreign equity in banking and insurance raised to } 60 \% \text { and } 90 \% \text { from } 49 \% \text {. For stock brokering, } \\
\text { limit can go to } 100 \% \text { with permission. Foreign investment in unit trusts permitted, if trust deed contains the } \\
\text { restriction to invest up to } 20 \% \text { in government securities. }\end{array}$ \\
\hline Taiwan & Mar-86 & First listed UK trust & & - & & \\
\hline Taiwan & Dec-86 & First closed end country fund & & - & & \\
\hline
\end{tabular}




\begin{tabular}{|c|c|c|c|c|c|c|}
\hline Taiwan & Jan-91 & Early official liberalization & & $\bullet$ & • & Approved foreign institutions can invest, with restrictions \\
\hline Taiwan & Apr-95 & First London listing & & - & $\bullet \bullet$ & \\
\hline Taiwan & May-96 & First listed ADR & & - & $\bullet \quad \bullet$ & \\
\hline Taiwan & Apr-99 & Subsequent official liberalization & & $\bullet$ & $\bullet \bullet$ & Easing of foreign ownership of listed stocks from $30 \%$ to $50 \%$. \\
\hline Thailand & Jul-85 & First listed UK trust & & $\bullet$ & & \\
\hline Thailand & Sep-87 & Early official liberalization & & $\bullet$ & & Alien Board facilitates foreign equity trading \\
\hline Thailand & Feb-88 & First closed end country fund & & $\bullet$ & • & \\
\hline Thailand & May-92 & Subsequent official liberalization & & $\bullet$ & $\bullet \bullet$ & Requirements for repatriation of dividends, capital gains, foreign currencies, and share certificates looser. \\
\hline Thailand & Jun-97 & Subsequent official liberalization & • & $\bullet$ & $\bullet \bullet$ & The BOT introduced a series of measures to limit capital inflows. \\
\hline Thailand & Nov-97 & Subsequent official liberalization & & $\bullet$ & $\bullet$ & $\begin{array}{l}\text { The BOT announced that foreign investors would be allowed to hold more than } 49 \% \text { of the shares in } \\
\text { existing financial institutions for a period of } 10 \text { years without the approval of the Ministry of Finance }\end{array}$ \\
\hline Turkey & Jul-89 & Early official liberalization & & $\bullet$ & • & Foreign investment in equities permitted \\
\hline Turkey & Dec-89 & First closed end country fund & & - & • & \\
\hline Turkey & Aug-90 & First listed UK trust & & - & - & \\
\hline Turkey & Jun-94 & Subsequent official liberalization & $\bullet$ & $\bullet$ & $\bullet \bullet$ & Exchange restrictions and fixed exchange rate effectively prohibit repatriation of capital. \\
\hline Turkey & Apr-95 & Subsequent official liberalization & & $\bullet$ & $\bullet \bullet$ & Exchange controls eliminated. \\
\hline Turkey & Feb-96 & First London listing & & $\bullet$ & $\bullet$ & \\
\hline Turkey & Jul-00 & First listed ADR & & $\bullet$ & $\bullet$ & \\
\hline Venezuela & Jan-90 & Early official liberalization & & $\bullet$ & & Foreign investment permitted in all except bank stocks \\
\hline Venezuela & Nov-91 & First listed ADR & & - & & \\
\hline
\end{tabular}

